\title{
Transcription of Kinetoplast DNA in Trypanosoma brucei Bloodstream and Culture Forms
}

\author{
J. H. J. Hoeijmakers, ${ }^{1}$ A. Snijders, J. W. G. Janssen, and P. Borst \\ Section for Medical Enzymology and Molecular Biology, Laboratory of Biochemistry, University of Amsterdam, \\ Jan Swammerdam Institute, F.O. Box 60.000, 1005 GA Amsterdam, The Netherlands
}

Received October 21, 1980; revised January 19, 1981

Kinetoplast DNA is the unusual mitochondrial DNA of trypanosomes. In Trypanosoma brucei it consists of about $10^{4}$ minicircles $(0.3 \mu \mathrm{m})$ and $10^{2}$ maxicircles $(6 \mu \mathrm{m})$ catenated into a single network. The maxicircles are probably the equivalent of mitochondrial DNA in other organisms. Here we report that a fraction of the total cellular RNA from bloodstream form and culture form $T$. bruce $i$ hybridizes with the maxicircle; we find no minicircle transcripts. Preferential hybridization with a $1.8-\mathrm{kb}^{2}$ maxicircle segment is shown to be due to two abundant RNA species, the $9 \mathrm{~S}$ and $12 \mathrm{~S}$ RNAs. After glyoxylation the apparent size of these putative rRNAs in gels is 1080 and 590 nucleotides, respectively; they are present in approximately equimolar amounts, lack poly(A) tails, their genes are adjacent, and they are transcribed from the same strand in the order $12 \mathrm{~S}-9 \mathrm{~S}$. Six additional RNA species, varying in size from 360 to 1110 nucleotides, are transcribed from segments covering $50 \%$ of the maxicircle. These transcripts are specifically retained on oligo(dT)-cellulose and presumably represent mitochondrial messenger RNAs. Recombinant DNA plasmids containing DNA

\footnotetext{
${ }^{1}$ Present address: Department of Cell Biology and Genetics, Erasmus University, 3000 DR Rotterdam, The Netherlands.

${ }^{2}$ Abbreviations used: kDNA, kinetoplast DNA; mtDNA, mitochondrial DNA; mtRNA, mitochondrial RNA; rRNA; ribosomal RNA; mRNA, messenger RNA; cDNA, complementary DNA; kb, kilobase pair(s); bp, base pair(s); DBM paper, diazobenzyloxymethyl-cellulose paper; VSG, variant surface glycoprotein.
}

complementary to two of these kinetoplast RNAs have been constructed and used as probes for the study of the corresponding genes. One of these complementary DNAs hybridizes with nonadjacent fragments of the maxicircle and this gene may, therefore, contain an intervening sequence(s).

Bloodstream trypanosomes, in which the synthesis of a mitochondrial respiratory chain is totally repressed, contain a 5 to 10-times lower level of maxicircle transcripts than cultured trypanosomes, in which the mitochondria are fully developed. This decrease affects all mitochondrial transcripts analyzed approximately to the same extent. Controls at the level of mitochondrial protein synthesis or membrane assembly may, therefore, contribute to the repression of mitochondrial synthesis in bloodstream-form trypanosomes.

Trypanosomes are unicellular parasitic flagellates, characterized by the unique kinetoplast DNA (kDNA) that is found in a specialized portion of the single mitochondrion of these organisms. In DNA-protein monolayers prepared for electron microscopy, kDNA appears to consist of $10^{3}-10^{4}$ small circular molecules (minicircles) catenated into a complex network (reviewed by Simpson, 1972; Borst and Hoeijmakers, 1979a; Englund, 1981). Depending on the species, minicircles vary in size from 0.25 to $0.8 \mu \mathrm{m}$ (Simpson, 1972); as shown by restriction enzyme analysis, their base sequence is usually heterogeneous (Borst and Hoeijmakers, 1979a), and very different in closely related species (Borst and Hoeij- 
makers, 1979b). They are not transcribed in two of the three trypanosome species studied (Hoeijmakers and Borst, 1978; Borst and Hoeijmakers, 1979b; Fouts and Wolstenholme, 1979).

Enzymatic dissection of kDNA with restriction endonucleases has further uncovered the presence of 50-100 maxicircles in the network (Kleisen et al., 1976a; Fairlamb et al., 1978). Accumulating data strongly suggest that the maxicircle codes for gene products similar to those encoded by the mitochondrial DNA (mtDNA) of other organisms: its size (ranging from $6 \mu \mathrm{m}$ in $T$. brucei to $12.5 \mu \mathrm{m}$ in Trypanosoma cruzi) and complexity are in the same order of magnitude as mtDNA of other organisms; it has a unique, strongly conserved base sequence; in trypanosomes that have lost the ability to make a functional mitochondrion often (part of) the maxicircle is lacking; and maxicircles are transcribed (Hoeijmakers and Borst, 1978). Two major mitochondrial RNA (mtRNA) species ( $9 \mathrm{~S}$ and $12 \mathrm{~S}$ ), transcribed from the maxicircles, have been identified in Leishmania (Simpson and Simpson, 1978) and the possibility has been raised that these are the mitochondrial ribosomal RNAs (rRNAs) (Borst and Hoeijmakers, 1979a).

In this paper we present our studies on kDNA transcription in $T$. brucei. This pathogen causes sleeping sickness in mammals and shares with yeast the unusual ability to repress completely mitochondrial biogenesis and live by glycolysis alone. Some of the results of this work have been summarized in a recent review (Borst et al., 1980a).

\section{MATERIALS AND METHODS}

Growth of the organisms. Trypanosoma (Trypanozoon) brucei brucei, stock 427, cloned stabilates 60 and 118 were used in this study. The kDNAs of both organisms are indistinguishable by restriction enzyme analysis (see Borst et al. (1980b) for further details). The bloodstream form of this try- panosome was grown in rats under standard conditions (Fairlamb et al., 1978). Procyclic culture forms of the same $T$. brucei 427 stock were grown in the semidefined medium described by Brün and Schönenberger (1979). The generation time under these conditions exceeded $14 \mathrm{~h}$ and the maximal cell density was approximately $6 \times 10^{7}$ trypanosomes/ $\mathrm{ml}$. The insect trypanosome Crithidia luciliae was grown in Boné medium (Boné and Steinert, 1956) under conditions specified previously (Kleisen et al., 1975).

Isolation of nucleic acids. kDNA and nuclear DNA were extracted from bloodstream form $T$. brucei according to published procedures (Borst and Fase-Fowler, 1979; Borst et al., 1980c).

For the isolation of total cellular RNA from bloodstream and culture form trypanosomes a previously published modification of the hot phenol extraction procedure of Penman (1966) was used (Hoeijmakers et al., 1980). However, the concentration of sodium EDTA in the NET-100 buffer (100 $\mathrm{mM} \mathrm{NaCl}, 10 \mathrm{~mm}$ Tris- $\mathrm{HCl}(\mathrm{pH} \mathrm{8.0)}, 100$ $\mathrm{mM} \mathrm{Na}-\mathrm{EDTA}$ ) was reduced in later experiments to $25 \mathrm{~mm}$ (NET-25). Poly (A) ${ }^{+}$ enriched RNA was obtained by two cycles of oligo(dT)-cellulose chromatography (Hoeijmakers et al., 1980).

Treatment of DNA with restriction enzymes. The source and assay conditions for the endonucleases Pst I, HapII, BglI, SstI, HaeIII, Sau 96-I, EcoRI, HindIII, and MboI are specified elsewhere (Borst and FaseFowler, 1979), those for TaqI are described by Borst et al. (1980b). Restriction enzymes $M b o$ II, BspI, MspI, Bam HI, and HinfI (purchased from Biolabs) were incubated for $2 \mathrm{~h}$ at $37^{\circ} \mathrm{C}$ in $10 \mathrm{~mm}$ Tris $-\mathrm{HCl}(\mathrm{pH} \mathrm{7.5),8} \mathrm{mM}$ $\mathrm{MgCl}_{2}, 1 \mathrm{mM}$ dithiothreitol, and $0.1 \%$ gelatin. The digestion buffer for AluI (Biolabs) contained $100 \mathrm{mM} \mathrm{NaCl}$ in addition. Double digestions were carried out as described (Borst and Fase-Fowler, 1979).

Gel electrophoresis of DNA. Two conditions were used for the electrophoretic separation of DNA fragments in the $0.8-1.5 \%$ agarose gels: for optimal resolution in the 
low-molecular-weight range (1 kilobase pair (kb)) "high-voltage", electrophoresis was applied; larger DNA fragments were sizefractionated by the "low voltage" system (Borst et al., 1980b). For photography of ethidium bromide-stained gels we refer to Borst and Fase-Fowler (1979) and Kleisen et al. (1976b).

Nomenclature of restriction fragments. The nomenclature of restriction fragments and sites used is a modification of the system proposed first by Sanders et al. (1977) and further specified by Borst and FaseFowler (1979) and Borst et al. (1980b). Short-hand abbreviations for the enzymes used are: B, BamHI; G, BglII; R, Eco RI; D, HindIII; Ps, PstI; Ss, SstI; Xb, XbaI; E, HaeIII (BspI); Y, HapII (MspI); L, HhaI; U, Sau 96-I; M, MboI; N, MboII; $\mathrm{Q}, \operatorname{Taq} \mathrm{I}$; V, HinfI. Any site for a given enzyme is designated using the abbreviation of the enzyme followed by the number of the site for that enzyme lying clockwise on the physical map of Fig. 2, starting from the arbitrarily chosen $E c o$ RI site R1 (Borst and Fase-Fowler, 1979). Any fragment is identified by a combination of the designations of the terminal sites, the first abbreviation being the site encountered first going clockwise on the physical map of Fig. 2. The number behind each combination of sites gives the electrophoretic mobility of that fragment generated by the particular (combination of) enzyme(s). Fragments are numbered in order of increasing mobility; e.g., D3E2-4 is the fragment bordered by the third HindIII site (D3) and the second Hae III site (E2) mapped starting clockwise from R1 and it is the forth band in a HindIII + Hae III double digestion of the maxicircle. See legends to Figs. 2 and 11 for further details.

Gel electrophoresis of RNA. In most experiments the RNA was denatured by glyoxal treatment (McMaster and Carmichael, 1977) prior to electrophoresis. Untreated RNA is heated briefly $(1 \mathrm{~min})$ to $95-100^{\circ} \mathrm{C}$ to disaggregate. The RNA samples are layered in the presence of $5 \%$ Ficoll and a trace of diethylpyrocarbonate with Orange $\mathrm{G}$ as color marker. Electrophoresis is performed in 1.75-2.0\% agarose gels at room temperature for $75-120 \mathrm{~min}$ at $125 \mathrm{~mA}(150 \mathrm{~V})$ under ribonuclease-free conditions. The electrophoresis system used is essentially similar to the "high-voltage" DNA electrophoresis and is detailed elsewhere (Van Ommen et al., 1980).

Molecular-weight determination. The molecular weights of electrophoresed DNA fragments or RNAs are calculated from their mobility in the gel relative to a set of coelectrophoresed reference molecules. The following marker sets were used:

I. Phage lambda DNA and an Eco RI digest of phage lambda DNA (Thomas and Davis, 1975).

II. Phage T7 DNA, phage $\phi 29$ DNA, and an $E c o$ RI digest of phage $\phi 29$ DNA (Ito et al., 1976).

III. Phage $\phi X$ (replicative form) DNA digested with BspI (Sanger et al., 1977).

IV. Phage $\phi \mathrm{X}$ (replicative form) DNA digested with MspI (Sanger et al., 1977).

V. Yeast RNA $(1710 \pm 80$ and $3360 \pm 80$ nucleotides for the main rRNA components) (Philippsen et al., 1978).

VI. Escherichia coli RNA (2904, 1541 nucleotides for the main rRNA components) (Brosius et al., 1978, 1980).

Isolation of RNA and DNA fragments from gels. Electrophoretically separated RNA molecules were recovered from the gel by the method of Van Ommen et al. (1979). DNA fragments were isolated by adsorption to Sepharose-lysine (Osinga et al., 1981).

Electrophoretic separation of DNA strands. DNA strands were separated using the method of Goldbach et al. (1978a), which is based on differential binding of poly(UG) to the two lambda strands.

Transfer of nucleic acids to nitrocellulose filters. Restriction-fragmented DNA, separated on gels was denatured with alkali and blotted onto nitrocellulose filters essentially as described by Southern (1975). 
Transfer of nucleic acids to diazobenzyloxymethyl-cellulose (DBM) paper. Electrophoretically separated RNA or DNA fragments were treated in situ by alkali $(50 \mathrm{~mm}$ $\mathrm{NaOH}, 1 \mathrm{~h}$ ), neutralized with $0.2 \mathrm{M} \mathrm{Na}$ phosphate buffer ( $\mathrm{pH} \mathrm{6.5)} \mathrm{for} 20 \mathrm{~min}$ at $4^{\circ} \mathrm{C}$ and transferred to DBM paper (Alwine et al., 1977) in $25 \mathrm{~mm} \mathrm{Na-phosphate} \mathrm{(pH} \mathrm{6.5)} \mathrm{or}$ $0.2 \mathrm{M} \mathrm{Na-acetate}$ ( $\mathrm{pH} 4.0$ ) under ribonuclease-free conditions according to published procedures (Alwine et al., 1977; Van Ommen et al., 1979).

Preparation of labeled probes. Doublestranded DNA was labeled in vitro by nicktranslation (Rigby et al., 1977) to a specific activity of $10^{7}-10^{8} \mathrm{cpm} / \mu \mathrm{g}$ using $\left[\alpha^{32} \mathrm{P}\right]-$ dATP and $\left[\alpha^{-32}\right.$ P]dTTP (The Radiochemical Center, Amersham; sp. act $2-3 \mathrm{Ci} / \mu \mathrm{mol}$ ) as the labeled nucleotides. RNA was fragmented to 200-400 nucleotides with alkali and labeled by polynucleotide kinase and $\left[\gamma^{32}{ }^{32}\right.$ ]ATP as described (Goldbach et al., 1978b). DNA markers labeled by polynucleotide kinase were kindly provided by Mrs. H. A. M. Hoeijmakers-Van Dommelen.

Hybridization with filter-bound nucleic acids. The hybridization conditions for DNA bound to nitrocellulose filters are specified by Hoeijmakers and Borst (1978). The same protocol was followed for hybridizations with nucleic acids covalently attached to DBM paper. In this case, however, the filters were incubated in the hybridization medium supplemented with $1 \%$ glycine for at least $3 \mathrm{~h}$ at $60^{\circ} \mathrm{C}$ prior to hybridization. In some experiments $10 \%(\mathrm{w} / \mathrm{v})$ dextran sulfate (Sigma) was included in the hybridization mixture to increase the hybridization efficiency (Wahl et al., 1979). To reduce the background of aspecifically bound radioactivity to acceptable levels it was necessary to wash the filters extensively after hybridization. Autoradiographic exposure of hybridized filters was for 2-20 days.

Construction of recombinant plasmids containing DNA complementary to maxicircle transcripts. The construction of doublestranded complementary DNA (cDNA) from total poly(A) ${ }^{+}$RNA from $T$. bruce 427-118 (bloodstream form), insertion in the Pst I site of plasmid pBR322 by the GC tailing technique and subsequent transformation of $E$. coli strain X-1776 have been described elsewhere (Hoeijmakers et al., 1980). However, size-fractionation of the cDNA was omitted. Transformants were screcned by the high-density colony-filter hybridization technique (Hanahan and Meselson, 1980) using ${ }^{32}$ P-labeled kDNA as probe essentially as described (Hoeijmakers et al., 1980) except that poly(A) was not included in the hybridization solutions. Colonies were picked from the nitrocellulose filters and grown under conditions specified (Hoeijmakers et al., 1980). For chloramphenicol amplification and purification of plasmid DNA we refer to Wilkie et al. (1979). The construction of the recombinant DNA clone bank was carried out under P3-EK2 containment conditions.

\section{RESULTS}

\section{Characterization of $k R N A$ from \\ Bloodstream Trypanosomes}

RNA from bloodstream $T$. brucei was screened for kDNA transcripts by two types of hybridization experiments:

1. In vitro labeled total cellular RNA was hybridized with Southern filters containing electrophoretically separated restriction enzyme fragments of trypanosomal DNAs. RNA hybridized to the filter-bound DNA was visualized by autoradiography. Figure 1 presents the result of one such experiment. The photograph of the ethidium-stained gel with restriction digests of $T$. brucei kDNA shows maxicircle fragments in the upper part of the gel and more prominent minicircle bands in the lower regions (panel I). The corresponding autoradiogram (panel II) shows only maxicircle fragments hybridizing, a picture similar to what we have seen in the insect trypanosome C. luciliae (Hoeijmakers and Borst, 1978). This hybridization is specific and not attributable to nuclear 


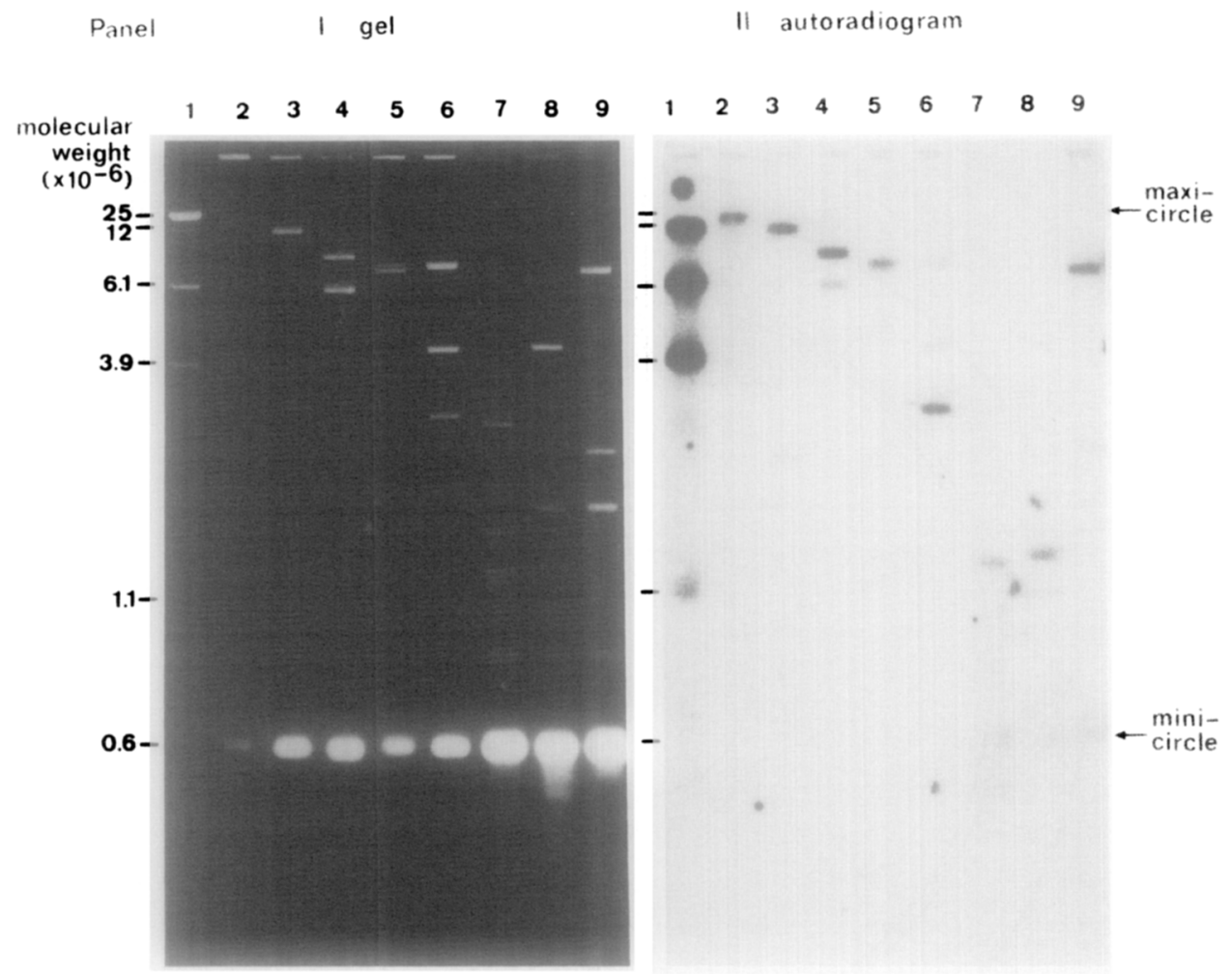

FIG. 1. Hybridization of total cellular RNA from bloodstream $T$. brucei with restriction fragments of kDNA. kDNA $(0.25 \mu \mathrm{g}$, panel I) of $T$. bruce $i$ was electrophoresed in $0.8 \%$ agarose after digestion with the following restriction endonucleases. Lanes: 2, Sst I; 3, HaellI; 4, HapII; 5, BglI; 6, Eco RI; 7, $A l u \mathrm{I} ; 8, \mathrm{Mbol} ; 9$, Sau 96-I. The AluI digestion is not complete. The DNA was denatured in situ, transferred to a nitrocellulose filter by the Southern technique, and hybridized with in vitro labeled total cellular RNA from $T$. brucei bloodstream form. Panel II shows the autoradiogram of the gel of panel I (after 2 weeks exposure). Lanes 1 contains molecular weight marker set II.

DNA contamination in the kDNA, because nuclear DNA digested with the same set of enzymes gives entirely different hybridization patterns (not shown). The most prominently hybridizing maxicircle fragment (Fig. 1, lanes 7-9) is localized on the $T$. brucei maxicircle map between sites D3 (HindIII) and E2 (HaeIII) (see Fig. 2), covering a region of $1.8-2.0 \mathrm{~kb}$ (see also Borst and Hoeijmakers, 1979b). An analogous predominantly transcribed maxicircle segment of only $1.5 \mathrm{~kb}$ is found in C. luciliae and C. fasciculata (unpublished observations).

2. To obtain more information on the RNA(s) that hybridize to kDNA fragments, we have carried out "Northern" or "RNA blot" hybridization experiments using elec- trophoretically fractionated, filter-bound RNA and in vitro labeled kDNA probes. Upon electrophoresis in agarose gels, total cellular RNA of $T$. bruce $i$ shows three highand at least five low-molecular-weight components (Fig. 3, panel I, lane 3). This unusual profile resembles that of other trypanosomatids like Crithidia (panel I, lane 2) in which case it has been demonstrated that the rRNA from the large subunit of cell-sap ribosomes contains in vivo at least one-possibly more-hidden breaks (Spencer and Cross, 1976; Garvin et al., 1978; Morales and Roberts, 1978; Gray, 1979). Similarly, the large rRNA of $T$, brucei cell-sap ribosomes disappears upon heat denaturation and generates at least two lowermolecular-weight RNA components, indi- 


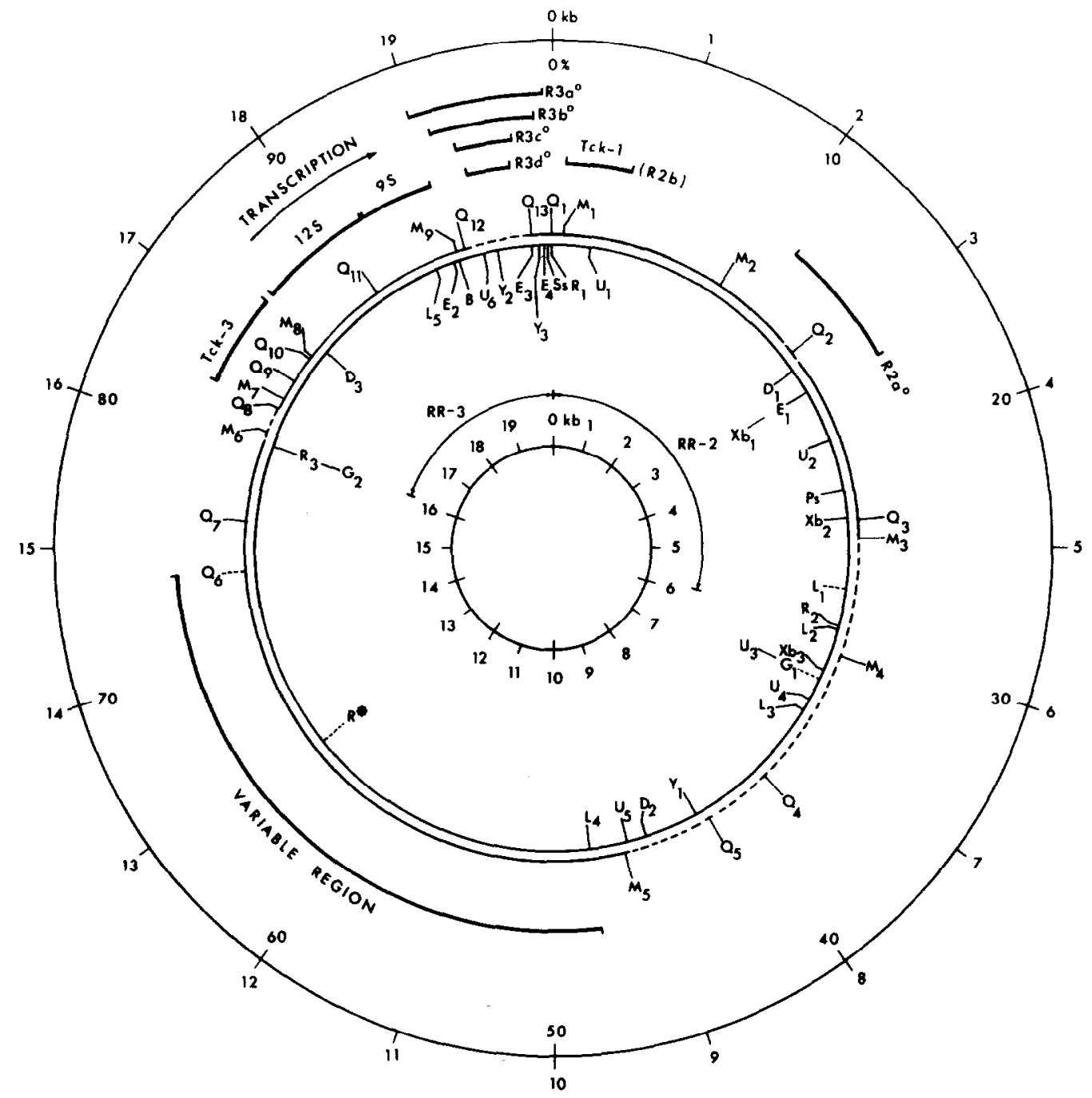

FIG. 2. Partial transcription map of the maxicircle of $T$. brucei 427. The location of the recognition sites for most of the enzymes is from Borst and Fase-Fowler (1979). The position of (some of) the TaqI and $M b o I$ sites is deduced in part from experiments presented here or elsewhere (Borst $e t$ al., $1980 \mathrm{~b})$ and in part from unpublished experiments: Interrupted regions indicate maxicircle segments with many sites (for the enzyme bordering the region) of which the exact position is not known. The genes for the $9 \mathrm{~S}$ and $12 \mathrm{~S}$ RNA species and Tck-1, -2 and Tck-3 are indicated by the heavy bars. The location of the genes for the other RNA species (indicated with ${ }^{\circ}$ ) is not further determined within RR-2 or RR-3 and they are, therefore, placed arbitrarily. The direction of transcription of the 9 S and 12 S RNA genes, deduced from Figs. 7 and 8, is indicated by an arrow. For a detailed map of this region including also sites for the enzymes $H$ infI and $M$ boll, we refer to Fig. 11. Polymorphic sites (Borst et al., 1980b) are connected to the circle by an interrupted line. $\left({ }^{*}\right)$ Indicates the polymorphic site absent in $T$. bruce 427 . The size of the RR-3 fragment is reduced to $4 \mathrm{~kb}$ (instead of the $4.7 \mathrm{~kb}$ of Fig. 11) to fit earlier size determinations; all fragments within RR-3 are reduced by the same factor. Details on the "variable region" can be found in Borst et al. (1980b). B, Bam HI; D, HindIII; E, Hae III; G, BglII; L, HhaI; M, MboI; Ps, PstI; Q, TaqI; R, EcoRI: Ss, SstI; U, Sau 96I; Xb, XbaI; Y, HapII (from Borst et al., 1980a). 


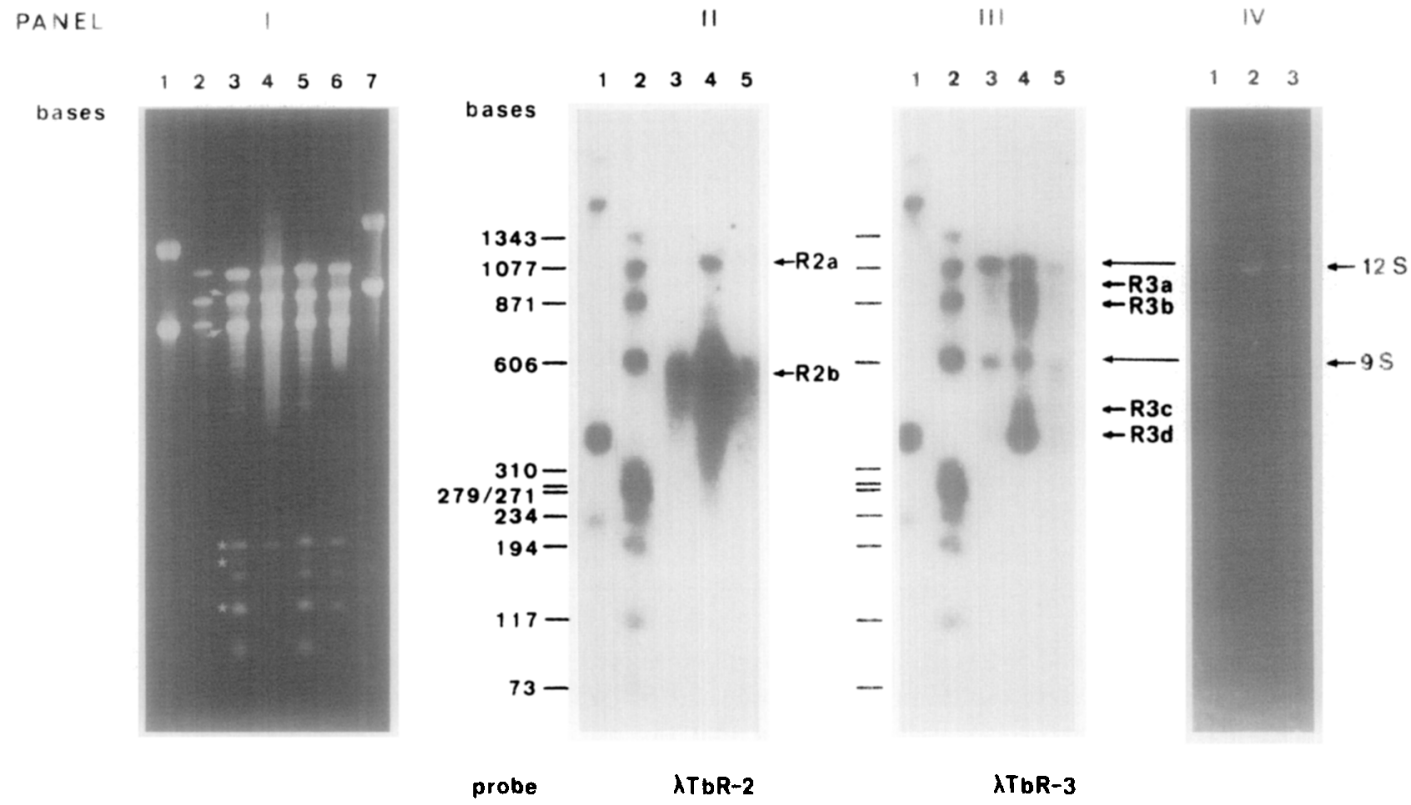

FIG. 3. Hybridization of size-fractionated RNA of $T$. brucei (bloodstream form) with cloned maxicircle fragments. $3 \mu \mathrm{g}$ of total cellular RNA, RNA enriched in poly $(A)^{+}$RNA by two cycles of oligo(dT)cellulose chromatography (poly(A) ${ }^{+}$RNA) and the unbound fraction (poly(A) ${ }^{-}$RNA) from T. brucei bloodstream form was denatured by glyoxal treatment (except for panel I), electrophoresed in $1.8 \%$ agarose, and transferred to activated DBM paper. The filter-bound RNA was hybridized with ${ }^{32} \mathrm{P}$ labeled lambda $\cdot$ TbR-2 and lambda $\cdot$ TbR-3 maxicircle probes. Panel I: the ethidium-stained gel containing total cellular RNA from $C$. luciliae (lane 2); $T$. brucei bloodstream form (3); the corresponding poly (A) ${ }^{+}$(4) and poly(A)- RNA (5); RNA from purified $T$. brucei cell-sap ribosomes (6); as molecular weight markers $E$. coli rRNA ( 1 and panel IV, lane 1) and yeast rRNA (7). To visualize the RNA species better, these samples were not treated with glyoxal prior to layering. The arrowheads in lane 3 indicate RNA fragments that are generated from the large subunit rRNA upon heat denaturation of the RNA. Asterisks point to RNA species found to be associated with rRNAs upon size fractionation on a Sephacryl S300 column of total cellular RNA (unpublished). Panels II and III: the autoradiograms of filter-bound RNA after hybridization with lambda-TbR-2 (panel II) and lambda-TbR-3 (panel III). The RNAs were: lanes 3, total cellular RNA; 4, poly $(A)^{+}$RNA; 5, poly(A)- RNA (in lane 5 of panel III less RNA was layered). Prior to electrophoresis the RNA samples were denatured by treatment with glyoxal. After ethidium staining they show a pattern as depicted in lanes 2 and 3 of panel IV. The arrows indicate the position of the bands of the presumptive $9 \mathrm{~S}$ and $12 \mathrm{~S} \mathrm{mtRNAs}$. The ${ }^{32} \mathrm{P}$-labeled molecular-weight markers are: lane 1, phage $\phi$ X174 DNA (RF) digested with BspI; 2, digested with $M s p I$. The gel of panel IV is from a separate run.

cated in lane 3 by arrowheads (experiments not shown). In fact, the results with RNA extracted from purified ribosomes indicate that all prominent RNAs (except for the $4 \mathrm{~S}$ RNA) are of ribosomal origin (lane 6 , see also Cordingley and Turner (1980) and Simpson and Simpson (1978)). Total cellular RNA, enriched in poly $(A)^{+}$RNA by two cycles of oligo(dT) chromatography is electrophoresed in lane 4 , the corresponding, unbound fraction $\left(\operatorname{poly}(\mathrm{A})^{-}\right)$in lane 5 of Fig. 3.
Glyoxal-denatured RNA (McMaster and Carmichael, 1977) with the profile shown in panel IV (lanes 2 and 3) was transferred to activated DBM paper. To detect maxicircle transcripts, the filter-bound RNA was hybridized with two lambda $\cdot \mathrm{gt} \cdot \mathrm{WES} \cdot \mathrm{kDNA}$ recombinants, containing the second and third EcoRI maxicircle fragment (R1R2-2 and R3R1-3 in Fig. 2) (Brunel et al., 1980), further designated as lambda-TbR-2 and lambda-TbR-3, respectively. The cloned fragments together cover slightly more than 
TABLE 1

Properties of Maxicircle Transcripts

\begin{tabular}{cccccc}
\hline $\begin{array}{c}\text { Designation } \\
\text { RNA species }\end{array}$ & $\begin{array}{c}\text { Apparent } \\
\text { size }^{a}\end{array}$ & $\begin{array}{c}\text { Binding to } \\
\text { oligo(dT) }\end{array}$ & $\begin{array}{c}\text { Hybridization } \\
\text { with }\end{array}$ & $\begin{array}{c}\text { cDNA } \\
\text { clone }\end{array}$ & $\begin{array}{c}\text { Size } \\
\text { (bp) }\end{array}$ \\
\hline 12 S $^{b}$ & 1080 & - & RR-3 & & \\
9 S $^{b}$ & 590 & - & RR-3 & & \\
R-2a & 1110 & + & RR-2 & Tck-1,-2 & 540,540 \\
R-2b & 570 & + & RR-3 & & \\
R-3a & 920 & + & RR-3 & & \\
R-3b & 780 & + & RR-3 & & \\
R-3c & 440 & + & RR-3 & Tck-3 & 470 \\
R-3d & 360 & $?$ & RR-3 & & \\
R-3e & $?$ & & & & \\
\hline
\end{tabular}

${ }^{a}$ In nucleotides.

${ }^{b}$ The size of $9 \mathrm{~S}$ and $12 \mathrm{~S}$ RNAs in Leishmania determined on methylmercurihydroxide gels is 522 and 1022 nucleotides, respectively (Simpson and Simpson, 1978). We attribute the difference with our $T$. brucei values to differences in gel systems. It is possible that the true size of these RNAs is larger, as we have recently observed that the DNA fragments protected against $S_{1}$ nuclease by hybridization with $9 \mathrm{~S}$ and $12 \mathrm{~S}$ RNAs are about 640 and $1230 \mathrm{bp}$, respectively.

$50 \%$ of the maxicircle. The smallest EcoRI fragment (RR-3; see Fig. 2), which shows the strongest hybridization in Fig. 1 (lane 6), hybridizes with two major and at least four minor RNA species (Fig. 3, panel III, lanes 3 and 4). RR-2 hybridizes only with two minor RNAs (Fig. 3, panel II).

Table 1 compiles some of the properties of these RNA molecules. We presume that the two major RNAs are identical to the $9 \mathrm{~S}$ and $12 \mathrm{~S}$ RNAs described by Simpson and Simpson (1978) in Leishmania mitochondria for the following reasons:

1. They are similar in size (see Table 1).

2. They are the most abundant (mitochondrial) RNAs (Fig. 3).

3. They are not specifically retained on oligo(dT)-cellulose (in contrast to all minor RNA species; Fig. 3).

4. After glyoxal denaturation, which blocks GC base pair formation, the 9 and $12 \mathrm{~S}$ RNAs stain relatively stronger with ethidium bromide than the other RNAs (compare panels I and IV of Fig. 3). This suggests that they have a high $\mathrm{A}+\mathrm{U}$ content (as reported for the $9 \mathrm{~S}$ and $12 \mathrm{~S}$ RNA (Simpson and Simpson, 1978)) that stabilizes their secondary structure.

\section{Comparison of Bloodstream and Culture form $k R N A$}

In the mammalian bloodstream, T. brucei relies for its energy supply on glycolysis alone and $\mathrm{CN}^{-}$-sensitive mitochondrial respiration is completely absent. Mitochondrial respiration and oxidative phosphorylation are fully developed in the insect as well as in culture (see Borst and Hoeijmakers, 1979a). To see whether a correlation exists between mitochondrial activity and the transcription level of kDNA we compared in Fig. 4 the hybridization of total cellular RNA from bloodstream-form and culture-form trypanosomes to filter-bound DNAs. For proper comparison of both kRNA hybridizations (lanes 2-4), the autoradiograms of panel II (hybridization with culture form RNA) and panel III (hybridization with bloodstream form RNA) were exposed to give the same hybridization intensity with the nuclear DNA (lanes 5-7). Clearly, the overall level of kDNA transcripts is considerably increased in culture-form RNA and again only maxicircle transcripts are found.

Comparison of panels II and IV (which is a longer exposure of the kDNA part of panel III) suggests that the concentration of some 
kRNAs is affected more than of others (arrowheads). The significance of this is doubtful, however, since the relative hybridization intensities to different maxicircle parts varied sometimes also between different bloodstream-form RNA preparations (compare Fig. 1, lane 8, and Fig. 4, lane 3 of panel IV). The lack of specific differences between bloodstream- and culture-form RNA is confirmed by the "Northern" hybridization experiment presented in Fig. 5 (panels I and II). This shows that the concentration of all RNAs is affected to about the same extent at least with the two $E c o$ RI maxicircle fragments used as probes (for the hybridization with lambda.TbR-2 compare also Fig. 3, panel II).

\section{Characterization of Recombinant Plasmids \\ Containing Copy DNA Complementary to Maxicircle Transcription Products}

To study the precise genetic location, synthesis, and possible function of some of the transcription products identified above we have screened an Escherichia coli clone bank, constructed for the isolation of plasmids containing DNA complementary to variant surface glycoprotein (VSG) messenger RNAs (mRNAs) (Hoeijmakers et al., 1980) for the presence of recombinants with kDNA transcript sequences. This cDNA bank was made as described under Materials and Methods starting from total poly(A) ${ }^{+}$ RNA of bloodstream-form $T$. brucei which (as shown in Fig. 3, panels II and III, lanes 4) contains also maxicircle transcripts. Among the approximately $4 \times 10^{3}$ transformants screened in this way we have found 11 (weakly) hybridizing colonies (i.e., 0.3\%). Plasmid DNA from three of these recombinants (Tck-1, -2 , and -3 ) was prepared for further analysis. Since Tck-1 and Tck-2 were found to be cDNA clones derived from the same RNA, we present only the results for Tck-1 and Tck-3. The partially purified hybrid plasmids were characterized by re-

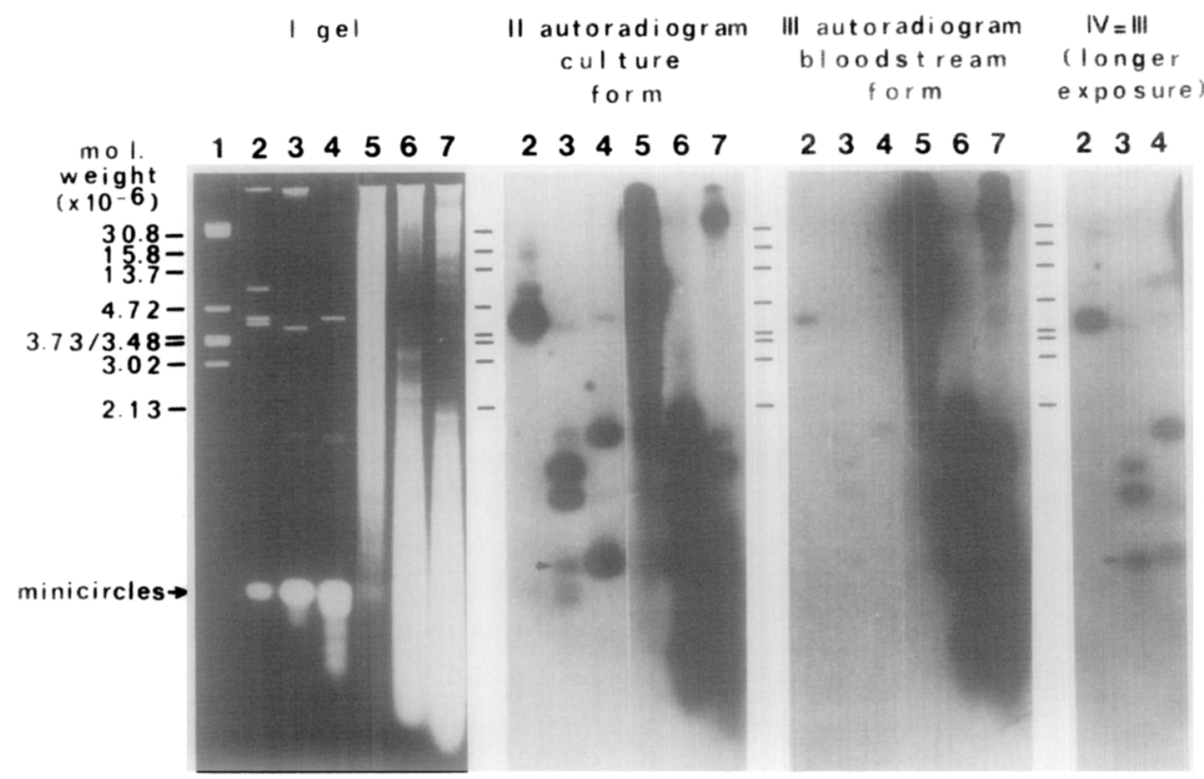

Fir. 4. Comparison of the hybridization of $T$. bruce $i$ culture-form and bloodstream-form RNAs with restriction fragments of kDNA and nuclear DNA. kDNA $(0.25 \mu \mathrm{g})$ and nuclear DNA $(1 \mu \mathrm{g})$ from T. bruce $i$ was digested with: lanes 2 and 5, HindIII; 3 and 6, MboI; 4 and 7, TaqI; and electrophoresed in $0.8 \%$ agarose together with molecular-weight marker set $\mathrm{I}$. The in situ denatured DNA was blotted onto nitrocellulose filters and hybridized with ${ }^{32} \mathrm{P}$-labeled total cellular RNA from $T$. brucei culture form (panel II) and bloodstream form (panels III and IV). The autoradiogram of panel IV is exposed about 3.5 times longer than that of panel III. The arrowheads indicate bands with a relative hybridization intensity that differs in bloodstream-form and culture-form RNAs. 
PANEL

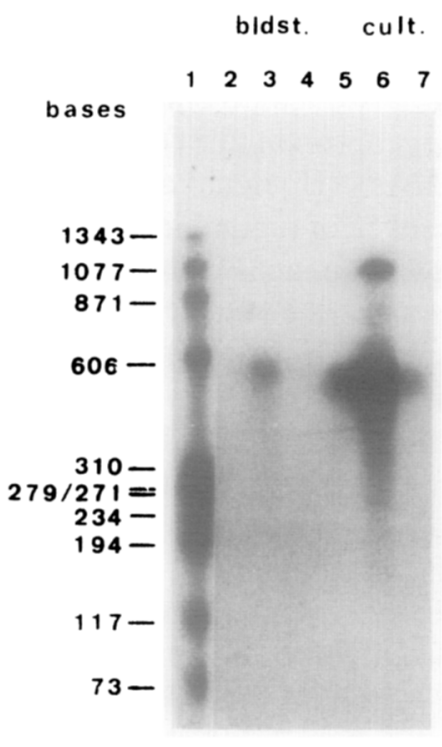

probe

ATbR-2

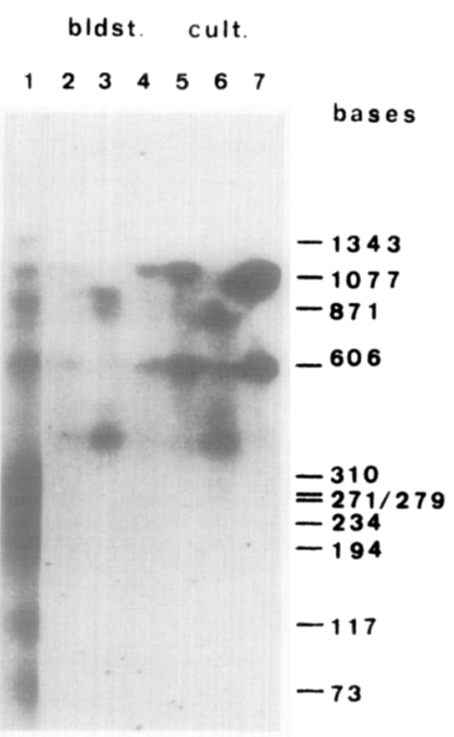

$\lambda T b R-3$
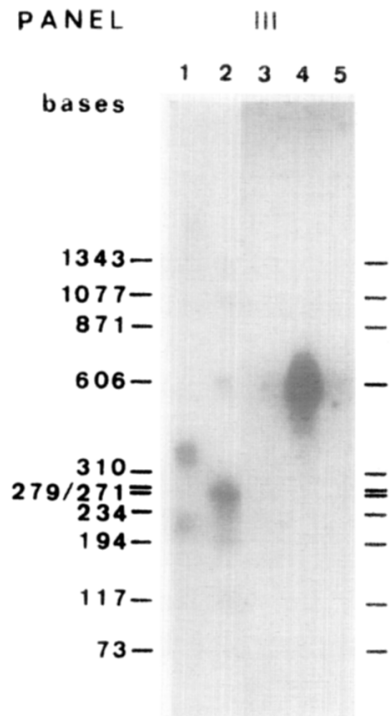

probe
Tck-1

FIG. 5. Comparison of the hybridization of size-fractionated RNA from $T$. brucei bloodstream-form and culture-form with cloned maxicircle fragments and cDNA clone Tck-1. Panels I and II: lanes 2 and 5 , glyoxal-denatured total cellular RNA; 3 and 6, poly(A) ${ }^{+}$RNA; 4 and 7, poly(A) ${ }^{-}$RNA of bloodstreamform (2-4) and culture-form (5-7) T. brucei. (The oligo(dT)-cellulose chromatography in this experiment has been more efficient in removal of the 9 and 12 S RNAs from the poly $(A)^{+}$RNA fraction than in the poly(A)+ RNA of Fig. 3.) The RNAs were electrophoresed in 2.0\% agarose, transferred to DBM paper, and hybridized with ${ }^{32}$ P-labeled lambda.TbR-2 and lambda.TbR-3 maxicircle probes (panels I and II, respectively). In each lane $3.0 \mu \mathrm{g}$ of RNA is layered except for lanes 5 and 6 where approximately $1 \mu \mathrm{g}$ of RNA was used. Panel I shows the autoradiogram after hybridization with the RR-2 cloned maxicircle fragment (exposure time about 2 weeks); panel II after hybridization with RR-3 (exposure time 5 days). Lane 1 , marker set III, labeled by polynucleotide kinase and $\left[\alpha^{-32}\right.$ P]ATP. Panel III, RNAs corresponding with lanes 5-7 of panels I and II were electropheresed and blotted as above. Hybridization of the filters was with labeled Tck-1. Lanes 1 and 2, marker sets IV and III, respectively, labeled as above.

striction enzyme analysis. Digestion with Pst I, which cleaves at the borders of the inserts (Bolivar et al., 1977), generates two main bands: the linearized plasmid and the insert band (Fig. 6, panel I, lanes 3 and 9). The sizes of the inserts are given in Table 1.

By digesting the plasmids with endonucleases TaqI, MboI (only with Tck-3), and MboII (only with Tck-1) either alone or in combination with PstI we have constructed the physical maps shown in the lower part of Fig. 11 (experiment presented in part in Fig. 6 , in part not shown). The electrophoresed plasmid DNA fragments shown in Fig. 6 were denatured in situ, blotted onto nitro- cellulose filters, and hybridized with labeled lambda.TbR-2 and -3 maxicircle probes. Figure 6, lanes 8 and 13 (corresponding to lanes 3 and 9. respectively) show that Tck-1 contains in insert homologous to the RR-2 probe and Tck-3 to the RR-3 probe, respectively. The RNAs from which the cDNA clones were derived were identified by Northern hybridization experiments. The autoradiogram of Fig. 5 (panel III) shows that Tck-1 is complementary to kinetoplast RNA R-2b, the main RNA component specified by RR-2 (compare lane 6 of panel 1 ). The same was found for Tck-2 (not shown). From Table I we conclude that both Tck-1 
and Tck- 2 cover more than $90 \%$ of the corresponding RNA, disregarding the contribution of the GC tails which usually do not exceed 30 base pairs (bp). The fact that Tck-1 and Tck-2 do not show hybridization with kinetoplast RNA R-2a suggests that this RNA is not a precursor of R-2b.

All attempts to identify in the same way the RNA from which Tck-3 was derived have failed. The most likely explanation for this is that the steady-state level of this transcript in the cell is too low for it to be detected by the Northern technique. This indicates at least that it is not one of the RNAs $\mathrm{R} 3 \mathrm{a}-\mathrm{d}$, because these can easily be detected in similar hybridization experiments using lambda $\cdot$ TbR-3 as probe (Fig. 3, panel III). More sensitive techniques (like protection against degradation by $S_{1}$ nuclease (Berk and Sharp, 1977)) are required to confirm this.
Determination of the Direction of

Transcription of the $9 S$ and I2 S RNA on the Maxicircle

The direction of transcription of the $9 \mathrm{~S}$ and 12 S RNA genes on the maxicircle was determined as follows: $9 \mathrm{~S}$ and $12 \mathrm{~S}$ RNA were purified by preparative agarose electrophoresis of glyoxal-denatured culture form RNA, followed by excision of the ethidium-stained RNAs (cf. Fig. 3, panel IV). Light and heavy chains of lambdaTbR-3 were separated by electrophoresis in the presence of poly(UG) (Goldbach $t t a l$, 1978a) and the separated strands hybridized with in vitro labeled $9 \mathrm{~S}$ and $12 \mathrm{~S}$ RNA. Both RNAs hybridize with the RR-3 strand that is inserted in the strand of lambda $\cdot \mathrm{gt} \cdot W E S$ with the highest mobility in gels (Fig. 7). The faster migrating strand corresponds to the light lambda chain (i.e., the strand with the

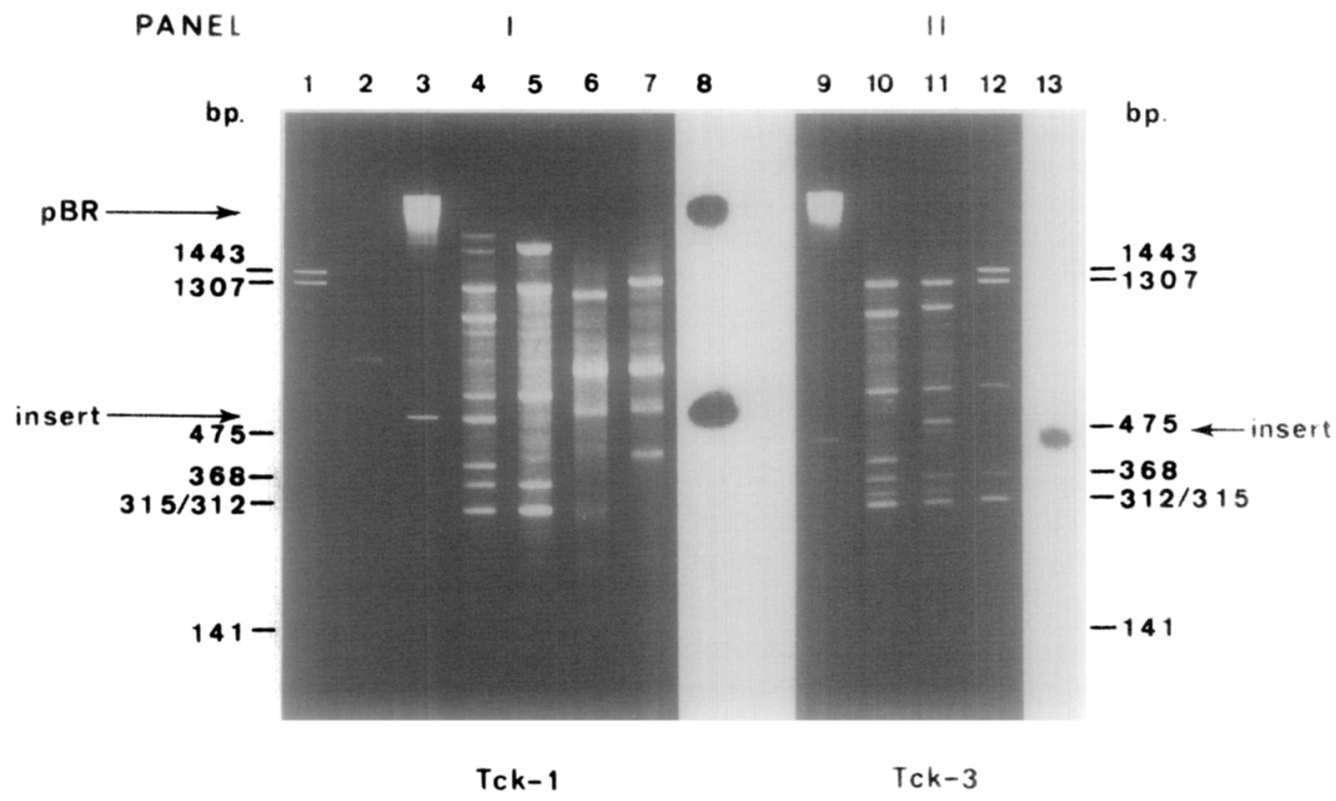

FIG. 0. Characterization of recombinant plasmids containıng cLNA trom maxicircle transcripts by restriction enzyme analysis and hybridization. $0.2-0.4 \mu \mathrm{g}$ of the (partly pure recombinant) plasmid DNAs Tck-1 (3-7), Tck-3 $(10,11)$, and pBR322 $(1,2,12)$ were digested with Pst I $(3,9)$, TaqI $(1,5,11,12)$, and TaqI + PstI $(4,10), M b o I I ~(2,7)$, and MboII + Pst I (6), and electrophoresed in 1.75\% agarose. After denaturation the DNA fragments were blotted onto nitrocellulose filters and hybridized with lambda.TbR-2 (8) and lambda·TbR-3 (13); only the autoradiograms of lanes 3 and 9 are shown (lanes 8 and 13, respectively). The $P_{s} I$ digestion in lane 3 is incomplete, as shown by the hybridization of the pBR band. For unknown reasons our MboII enzyme did not cleave the pBR322 DNA when a TC dinucleotide followed the GAAGA recognition sequence. 


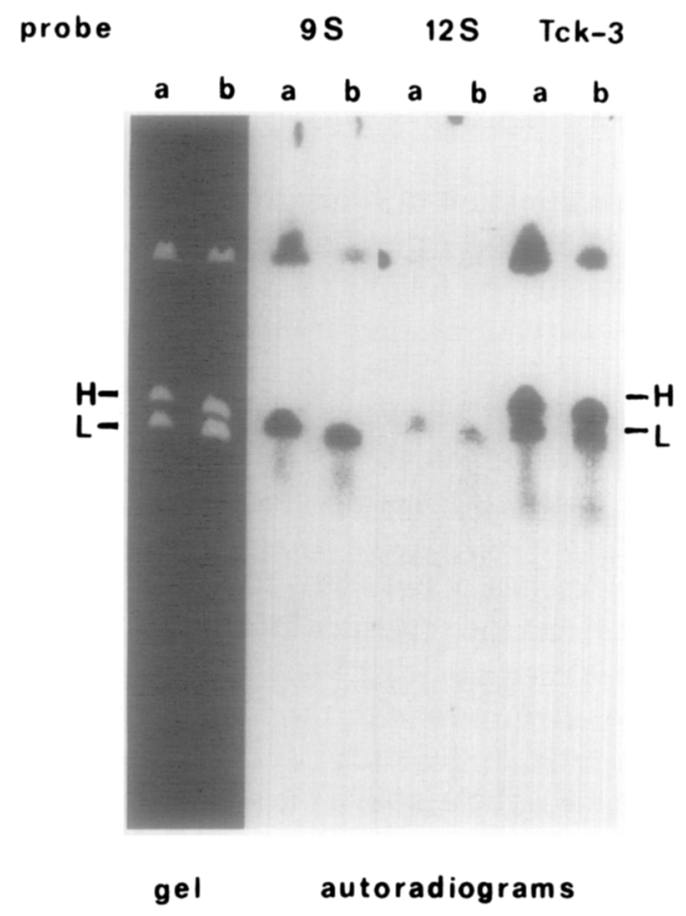

FIG. 7. Determination of the codogenic strand for $9 \mathrm{~S}$ and $12 \mathrm{~S}$ RNA in lambda.TbR-3. I ambda $\cdot$ TbR-3 $(0.4 \mu \mathrm{g})$ was briefly heated in the presence of poly(UG) (6 $\mu \mathrm{g}$ for lanes a and $3 \mu \mathrm{g}$ for lanes $\mathrm{b}$ ) and then electrophoresed in $0.3 \%$ agarose to separate the strands. The DNA was transferred to nitrocellulose filters and hybridized with labeled 9 S RNA, 12 S RNA, or lambda-TbR-3 DNA as indicated. $H$, heavy strand; L, light strand.

5 '-terminus at the left lambda arm (see Fig. 8 and Hradecna and Szybalski, 1967), assuming that the light and heavy lambda DNA strands are not reversed by the deletion of the middle lambda portion and the insertion of the RR-3 maxicircle fragment. (Sequence analysis of more than $50 \%$ of RR-3 indicates that there is no unequal $\mathrm{T}+\mathrm{G}$ distribution over both strands (I. C. Eperon, personal communication).) The control experiment with double-stranded cDNA clone Tck-3 shows that both strands are able to hybridize (Fig. 7); the hybridization with the highmolecular-weight band is due to the presence of native lambda TbR-3.

In principle the RR-3 fragment can be inserted in the lambda.gt $\cdot W E S$ vector in two orientations, depicted in Fig. 8 as alterna- tives $a$ and $b$. Because of the asymmetrical location of the single HindIII site in RR-3 (see Fig. 2, and Borst and Fase-Fowler, 1979) we expect upon cleavage with this enzyme a hybrid fragment of about $8.6 \mathrm{~kb}$ in case $a$ and of $6.6 \mathrm{~kb}$ in case b (see Fig. 8). The position of the HindIII sites in lambda DNA is deduced from Daniels et al. (1980) and Leder $e t$ al. (1977). The HindIII digest in Fig. 8, lane c-1, shows the presence of the 6.6-kb band as predicted from orientation $\mathrm{b}$, whereas an 8.6-kb fragment is absent. Hybridization with Tck-3 (lane c-2) confirms that the $6.6-\mathrm{kb}$ band is indeed one of the expected hybrid fragments, ruling out alternative a. Since the orientation of RR-3 in the maxicircle with respect to the HindIII site is known (Fig. 2), the direction of transcription must be as indicated in Figs. 2 and 11. The $9 \mathrm{~S}$ and $12 \mathrm{~S}$ RNA hybridization with the $24 \mathrm{~kb}$-hybrid fragment (Fig. 8, lanes c-3 and c-4) confirms that they are coded by the region clockwise from $\mathrm{D} 3$. On the other hand, Tck- 3 must reside (mainly) on the other side of D3 as deduced from the hybridization intensities. In the next section we will determine more precisely the position of these genes.

\section{Construction of a Detailed Physical Map of the $9 \mathrm{~S}$ and $12 \mathrm{~S}$ RNA Region and the} Genes Coding for Tck-1, Tck-2, and Tck-3

Since HindIII and BspI (isoschizomer of Hae III) cleave close to the borders of the $9 \mathrm{~S}$ and $12 \mathrm{~S}$ RNA region at approximately 2-kb distance from each other (see Fig. 2), we have mainly used these enzymes to position the sites for other endonucleases in this maxicircle fragment. Figure 9 shows gels (panel I) of kDNA digested with Hinf I (part A), TaqI (part B), and MboII (part C) in combination with BspI or HindIII. The corresponding autoradiograms, after hybridization with $9 \mathrm{~S}$ RNA, $12 \mathrm{~S}$ RNA, Tck-3, lambda $\cdot$ TbR-3, Tck-1, and lambda $\cdot$ TbR-2, are shown in panels II-VII, respectively. Results with MboI are shown in Fig. 10, lanes 4-7. On the basis of these data the 

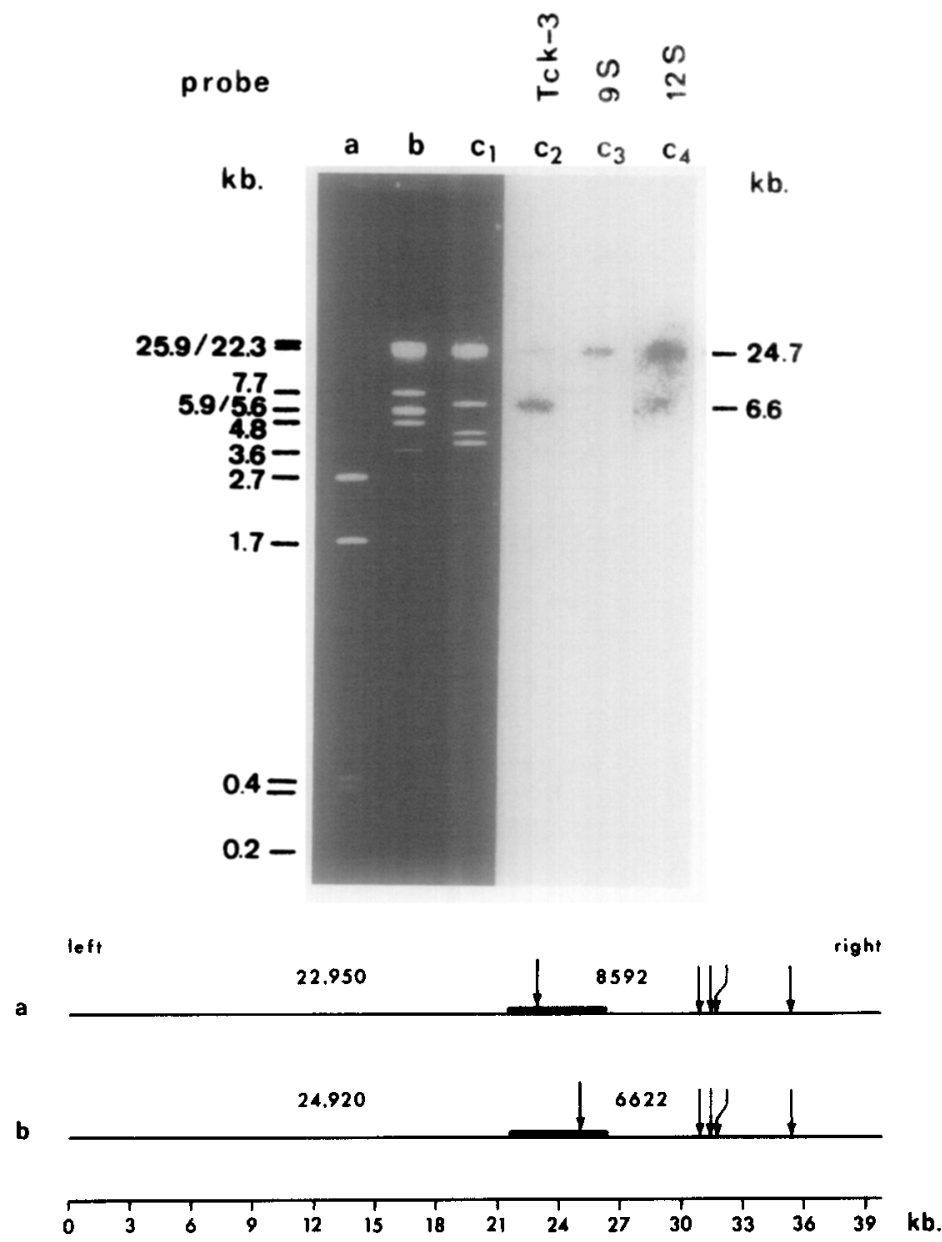

FIG. 8. Orientation of RR-3 in lambda $g t \cdot W E S-l a m b d a \cdot b$ vector. The bottom part gives the two possible orientations of RR-3 in the lambda $\cdot g t \cdot W E S-l a m b d a \cdot b$ vector DNA. The position of the HindIII sites in the lambda DNA are deduced from Leder et al. (1977) and Daniels et al. (1980). The size of the expected hybrid fragments is indicated. The $0.6 \%$ agarose gel containing lambda $\cdot$ TbR-3 after digestion with HindIII (lane $\mathrm{c} 1$ ) is depicted in the upper part, lanes a and b, molecular-weight marker sets IV and I, respectively. The corresponding lanes after hybridization with Tck-3,9 S, and 12 S RNA are indicated as c2-c4, respectively.

final fragment map given in Fig. 11 was constructed. An Appendix to this paper describing the construction of this map is available on request. Here we shall restrict ourselves to the main conclusions and some comments.

1. The only way to visualize maxicircle fragments smaller than the $1-\mathrm{kb}$ minicircles is by hybridization. It is, therefore, possible that small fragments (smaller than $200 \mathrm{bp}$ ) go undetected if they are not efficiently retained on the nitrocellulose filter.
2. All sites are mapped with respect to the HindIII and BspI ( Hae III) recognition sites. Only in some instances has the position of sites been determined relative to that for Eco RI and HapII in addition (Fig. 10). As a consequence, the position of sites relative to each other may vary slightly, depending on inaccuracies in fragment size determination and the undetected presence of small fragments.

3. The $9 \mathrm{~S}$ RNA probe is contaminated with the comigrating R-2b RNA (cf. Fig. 3, 


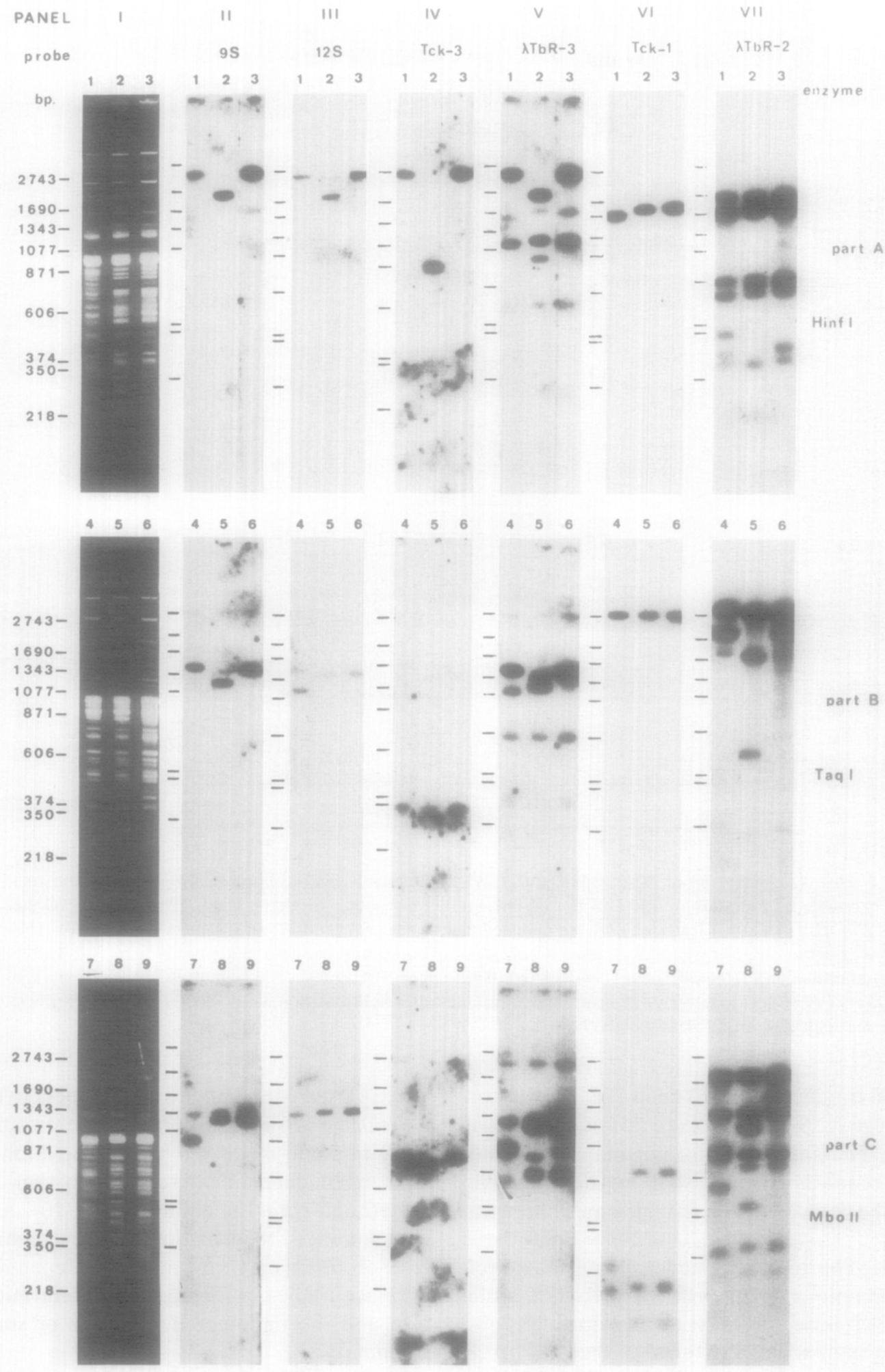


panels II and III) and contains in addition traces of degraded 12 S RNA (see e.g., panel II of Fig. 9, lanes 3, 7-9).

4. The TaqI map contains some "gaps" indicated in Fig. 11 by a question mark. This is due to the presence of clusters of TaqI sites, resulting in many small fragments that could not be located precisely as explained in the Appendix.

5. The exact order for the three small $M b o$ II fragments in the gene coding for Tck-1 was not established and the order given in Fig. 11 is arbitrary (see Appendix).

The map of Fig. 11 allows a fairly accurate determination of the borders of the single genes for $9 \mathrm{~S}$ and $12 \mathrm{~S}$ RNA. The $12 \mathrm{~S}$ gene should start just beyond D3 and end close to N4. The space between the $9 \mathrm{~S}$ and $12 \mathrm{~S}$ genes should be less than 350 bp since the 9 S hybridization stops before or close to the unique Bam HI site.

An interesting point following from the map is the hybridization of Tck-3. As explained in the Appendix, the Tck-3 hybridization extends to the left of $M b o$ II site N2 and $M b o$ I site $\mathrm{M} 7$ and to the right somewhere between M8 and D3: the TaqI fragment Q10Q11 (1170 bp), as well as the $\mathrm{MboI}$ fragment M8M9 (2300 bp), give clear hybridization (see Fig. 10, parts A and B). In some experiments a very weak hybridization is even found with a region beyond D3 (see Fig. 8); in the cDNA itself, however, the HindIII site is absent (data not shown). This demonstrates that the Tck-3 insert (460 bp) hybridizes with a region of approximately $800 \mathrm{bp}$. This is illustrated for instance by the hybridization of Tck-3 to the $\mathrm{MboI}$ digest (Fig. 10, part B, lane 4). Main hy- bridization is found with the 640-bp fragment (M7M8-7); weaker but distinct hybridization is observed with M8M9-3 (2300 bp) and M6M7-8 (460 bp). The most likely interpretation is that the gene from which the cDNA is derived contains intervening sequences that are removed from the primary transcript during processing. A preliminary map of the Tck-3 insert (Fig. 11, bottom line) shows that one $\mathrm{MboI}$ and probably one TaqI site are missing: one of the two TaqI sites in the cDNA is very close to the border and the region on the left-hand side (about $40 \mathrm{bp}$ ) is too short to form stable hybrids under the conditions used, especially when the GC linker is subtracted (approximately $20 \mathrm{bp}$ in other inserts from the same bank). The most logical interpretation is, therefore, that TaqI sites Q8 and Q10 are conserved, but that the middle $Q 9$ site is absent in the cDNA. Similar results were obtained with MboI (SauIIIA) for which two sites were expected in the cDNA whereas only one was found (Fig. 11). On the basis of these preliminary data it is not possible to localize the genomic region(s) that is (are) absent in the cDNA. On the other hand, all results with Tck-1 (and also $9 \mathrm{~S}$ and $12 \mathrm{~S}$ RNA) are compatible with continuous transcripts from these genes.

\section{DISCUSSION}

Our hybridization studies on kDNA transcription in $T$. brucei have confirmed that the maxicircle is the genetically active component in the kDNA network and have led to the identification of at least eight discrete maxicircle transcripts, which are indicated on the partial transcription map of Fig. 2 .

FIG. 9. Construction of a detailed physical map of the regions containing the genes for $9 \mathrm{~S}$ and $12 \mathrm{~S}$ RNA and Tck-1 and Tck-3 for the enzymes $H i n f I, M b o I I$, and TaqI. kDNA $(0.5 \mu \mathrm{g})$ was digested with: lanes 1-3, HinfI; 4-6, TaqI; 7-9, MboII in single (lanes 3, 6, and 9) and double digestion with BspI (lanes 1, 5, and 7) and HindIII (lanes 2, 4, and 8). Three parallel gels with slight variations in DNA migration were used. After transfer of the denatured DNA to nitrocellulose filters hybridization was carried out with the six ${ }^{32}$ P-labeled probes indicated. Panel II, 9 S RNA; panel III, 12 S RNA; panel IV, Tck-3; panel V, lambda-TbR-3; panel VI, Tck-1; panel VII, lambda-TbR-2. The filters of panel II were reused for hybridization with lambda·TbR-3 (panel V), after removal of bound radioactivity by low-salt washing. 


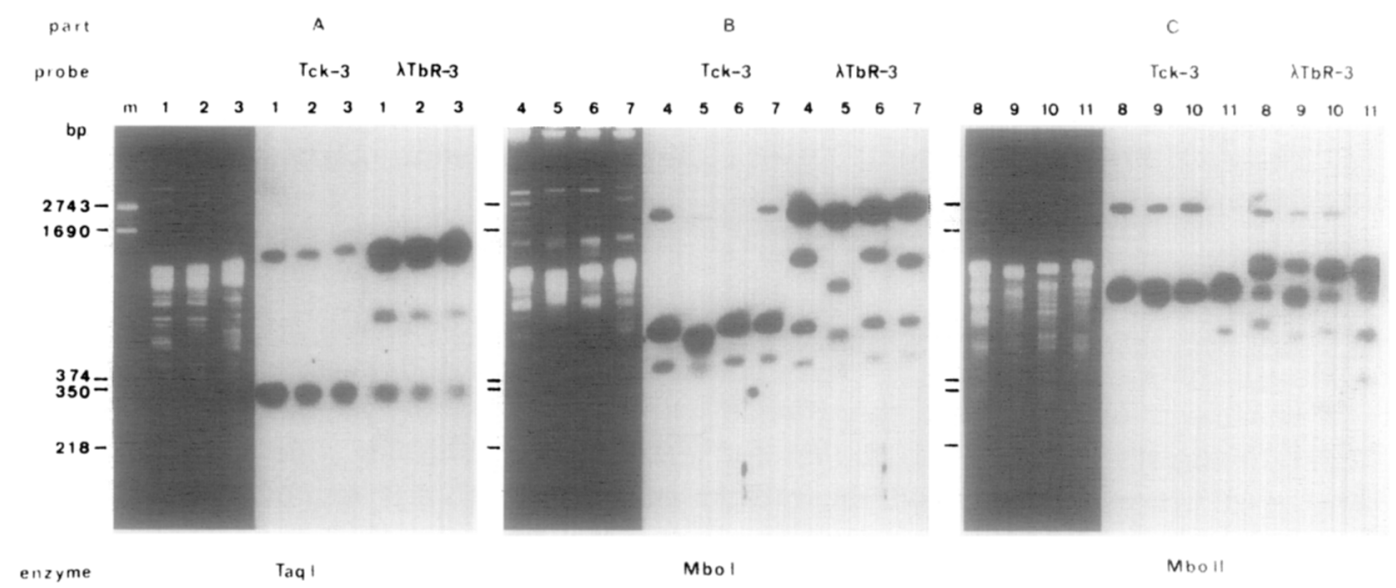

Fig. 10. Construction of a detailed physical map for RR-3 for the enzymes MboI, Mboll, and TaqI. kDNA $(0.3 \mu \mathrm{g})$ was digested with: lanes $1-3, T a q \mathrm{I} ; 4-7, M b o \mathrm{I} ; 8-11, M b o I I$ in single digestions (lanes 1,4 , and 8) and in combination with BspI (lanes 5 and 9), HindIII (lanes 6 and 10), Eco RI (lanes 3, 7, and 11), and Hap II (lane 2). The corresponding hybridizations with ${ }^{32} \mathrm{P}$-labeled Tck-3 and lambda $\cdot \mathrm{TbR}-3$ are indicated. Marker set III is electrophoresed in lane $\mathrm{m}$.

The $9 S$ and $12 S$ RNAs Are Mitochondrial rRNAs

The two major RNA species detected in RNA and DNA blots are the equivalent of the $9 \mathrm{~S}$ and $12 \mathrm{~S}$ RNAs discovered by Simpson and Simpson (1978) in the kinetoplast fraction of Leishmania tarentolae. The proposal that they represent mitochondrial rRNAs (Borst and Hoeijmakers, 1979a) is now supported by the following findings:

1. The $9 \mathrm{~S}$ and $12 \mathrm{~S}$ RNAs are the only major large RNAs found in trypanosome mitochondria. In all organisms analyzed thus far the major mitochondrial RNAs are the rRNAs.

2. The $9 \mathrm{~S}$ and $12 \mathrm{~S}$ RNAs are found in approximately equimolar amounts (see Fig. 3, panel III, lane 3).

3. Their sequence and size are strongly conserved in trypanosome evolution. Cheng and Simpson (1978) report no apparent differences between the RNAs from Leishmania tarentolae and Phytomonas davidi. We have found that the $9 \mathrm{~S}$ and 12 S RNAs of $T$. brucei and $C$. luciliae readily crosshybridize and have the same size (unpublished). Similar results were recently obtained for $T$. brucei and $L$. tarentolae by
A. M. Simpson and L. Simpson (personal communication).

4. In contrast to the other maxicircle RNAs, they are not selectively bound to oligo(dT), indicating the absence of long poly(A) tails.

5. There is only one gene for 9 S RNA and one for $12 \mathrm{~S}$ RNA and these are adjacent and encoded by the same strand (Figs. 2 and 11). Whether the two RNAs are synthesized from a common precursor remains to be determined.

6. We have provided Mr. Ian C. Eperon (M.R.C., Cambridge, U. K.) with the DNA segment containing the $9 \mathrm{~S}$ and $12 \mathrm{~S}$ genes and he has found that this segment shows homology with the rRNAs of human mitochondria and E. coli (personal communication).

We conclude from these data that the $9 \mathrm{~S}$ and 12 S RNAs are the major RNAs of the mitochondrial ribosome. With an apparent combined size of $1080+590=1670 \mathrm{nu}$ cleotides they are the smallest rRNAs known in nature, even much smaller than the mitochondrial rRNAs of Drosophila (Klukas and Dawid, 1976) and vertebrates (Dawid, 1972). This raises the possibility that the trypanosomal mitochondrial ribosome has unusual 


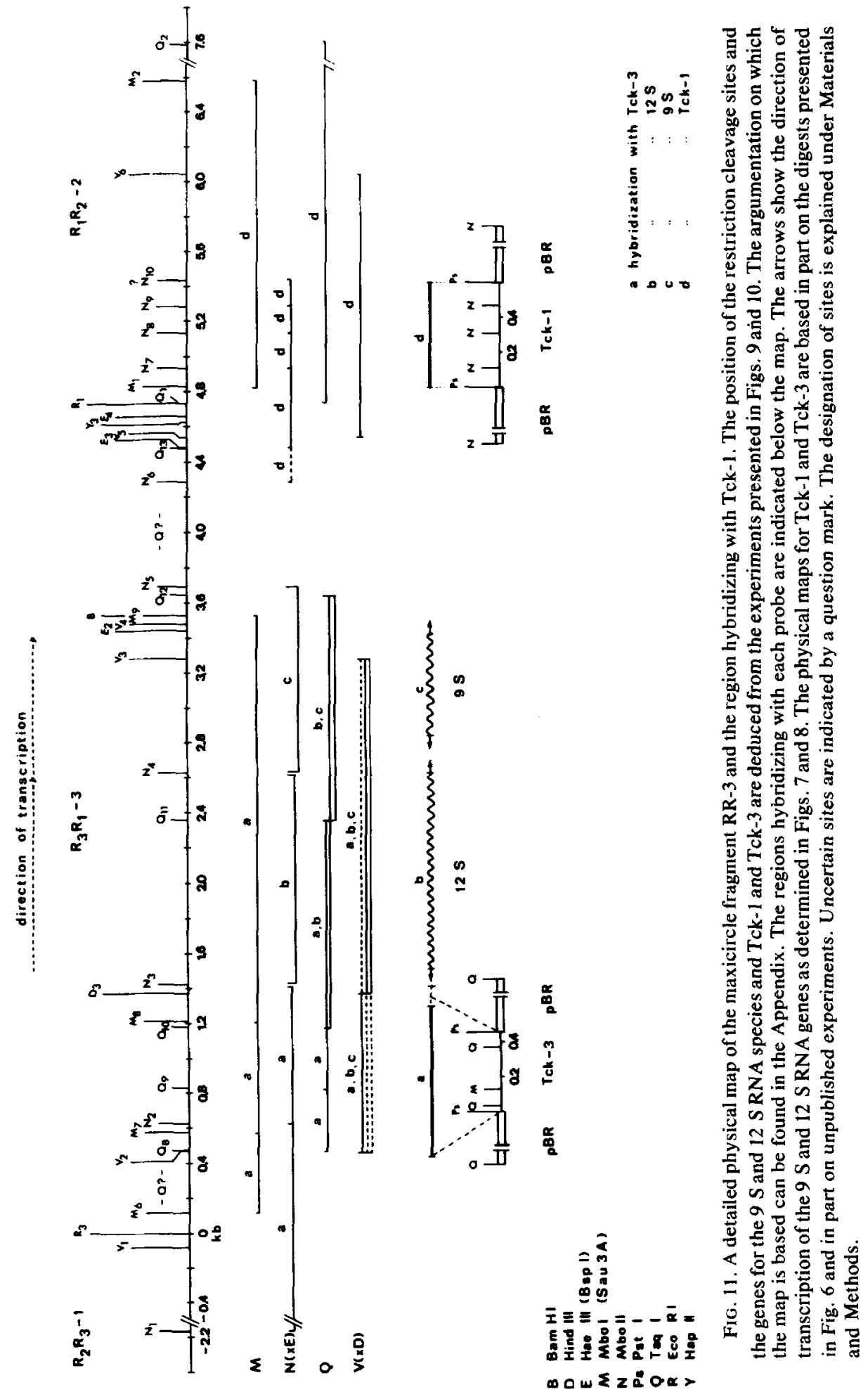


properties (e.g., a very high protein/RNA ratio) and this would explain why we and others have been unable to isolate it thusfar and why we have been unable to find evidence for mitochondrial protein synthesis in Crithidia using classical inhibitors of mitochondrial translation like chloramphenicol, ethidium, or spiramycin (Kleisen and Borst, 1975).

There are two other unusual features of the $9 \mathrm{~S}$ and $12 \mathrm{~S}$ rRNAs: the large RNA is $5^{\prime}$ to the small one, an arrangement also recently found in Leishmania mitochondria (L. Simpson, personal communication), but not in animal mitochondria or elsewhere in nature (Wolstenholme et al., 1979) (disregarding the unusual situation in Saccharomyces and Tetrahymena mtDNA, where the two genes are far apart (Sanders et al., 1975; Goldbach et al., 1978b)). Another unusual feature is the high AU content of close to 80 mol\% (I. C. Eperon, personal communication).

\section{The Minor RNAs}

Simpson and co-workers (Simpson and Lasky, 1975; Simpson et al., 1976) have reported that $9 \mathrm{~S}$ and $12 \mathrm{~S}$ RNA from Leishmania stimulated protein synthesis in a wheat germ system. Moreover, in hybridization experiments a large segment of the maxicircle was found to hybridize with both of these RNAs (Simpson and Simpson, 1978; Masuda et al. , 1979). Both results can be explained by our observation that at the position of the $9 \mathrm{~S}$ and $12 \mathrm{~S}$ two other RNA species migrate that will contaminate $9 \mathrm{~S}$ and 12 S RNA preparations purified on size. We think that these minor RNAs are mitochondrial messengers or mRNA precursors, because this could explain both the in vitro experiments of Simpson and co-workers and the binding to oligo(dT), which suggests the presence of poly(A) tails.

It is remarkable that the RNAs found thus far are so small. Mitochondrial precursor RNAs or mRNAs in yeast are much longer (Grivell et al., 1979; Van Ommen et al., 1979) and the minimally required coding sequence for, e.g., subunit I of cytochrome oxidase and the apocytochrome $b$ protein in Neurospora and yeast mitochondria exceeds our longest maxicircle transcript (Borst and Grivell, 1978; Werner and Bertrand, 1979). It is possible that longer transcripts have been missed in our experiments. Their concentration could be below our detection level; they could have been lost specifically during isolation or they could be coded for by the maxicircle fragment RR-1, which has resisted cloning in E. coli (Brunel et al., 1980). The latter possibility is not unreasonable because maxicircle transcripts longer than $12 \mathrm{~S}$ RNA have recently been found in Leishmania (A. M. Simpson and L. Simpson, personal communication). Alternatively, the genes for the larger mitochondrial proteins might reside in the nucleus (like the gene for the DCCD-binding protein in Neurospora (Sebald et al., 1977)) or the protein corresponding to subunit I of oxidase and apocytochrome $b$ could be smaller or absent in trypanosomes.

From the hybridization data of RR-3 (see Fig. 2) it seems that this maxicircle segment is crowded with genes, a situation that also is found in Leishmania (L. Simpson, personal communication). The added molecular weights of all hybridizing RNAs $(4170$ nucleotides) plus the Tck-3 region (at least $700 \mathrm{bp}$ ) even exceed the size of RR-3 (4700 $\mathrm{bp})$. Moreover, this active region extends in RR-2, because the R-2b gene is situated very close to the border with RR-3 (Fig. 11). It is possible that some of these transcripts are precursor or degradation products of others. The presence of interrupted genes on the maxicircle is suggested by the hybridization with Tck-3 (Fig. 11), for which we were unable to detect the corresponding transcript, probably because it is present in very low concentrations. However, the possibility has to be ruled out that rearrangements have occurred during construction of the cDNA hybrid and subsequent growth in $E$. coli, although analysis of 31 (VSG) cDNA clones from the same bank has provided no 
indications for such artifacts (Hoeijmakers et al., 1980). The data for the other genes studied (9 S, 12 S RNA and Tck-1) are all compatible with a continuous coding sequence; small intervening sequences could obviously have been missed, however.

No maxicircle tRNAs have shown up in our hybridizations. This is not due to inefficient binding of tRNA-sized molecules to the filter; a 73-bp DNA marker is clearly visible on the autoradiograms (see Figs. 3 and 5). However, it is possible that our hybridization conditions were too stringent for efficient $4 \mathrm{~S}$ hybridization since analogous experiments with yeast mitochondrial tRNAs are carried out under conditions equivalent to $9-10^{\circ} \mathrm{C}$ below our hybridization temperature.

\section{Mitochondrial Biogenesis}

The repression of mitochondrial respiration and oxidative phosphorylation in the bloodstream form was shown to correlate with a 5- to 10-fold decrease in the level of maxicircle transcripts. From the RNA blots (Fig. 5) we conclude that all transcripts are affected to approximately the same extent. This cannot readily account for the differential repression of mitochondrial enzymes, the respiratory chain being completely absent, whereas an oligomycin-sensitive ATPase (Opperdoes et al., 1976) which presumably requires mitochondrially synthesized subunits like in yeast (Borst and Grivell, 1978), is still present. There may be, therefore, an additional control at the level of mitochondrial translation or membrane assembly.

\section{Minicircle Transcription}

As in our previous studies with Crithidia we have not found RNA complementary to the minicircles. In contrast, Fouts and Wolstenholme (1979) have recently reported the detection of a 240-nucleotide RNA, homologous to the heavy strand of the minicircles in Crithidia acantocephali. This RNA seemed to be present in the kinetoplast frac- tion as well as in the cytoplasm in the same (high) concentrations. Such an RNA should have been readily detectable in our experiments if present in $T$. brucei or C. luciliae. We cannot account for this discrepancy. Nevertheless, we think that most of the data now available make it unlikely that minicircles code for an essential protein or structural RNA. The high-sequence heterogeneity of minicircles in some species (Steinert et al., 1976; Steinert and Van Assel, 1980; Donelson et al., 1979) and the high rate of sequence evolution of this DNA (Borst and Hoeijmakers, 1979b; Borst et al., 1980b) and the recent results of sequence analysis of minicircles (Chen and Donelson, 1980) support this view. Why trypanosomes have minicircle networks remains to be determined.

\section{ACKNOWLEDGMENTS}

We thank Dr. F. R. Opperdoes (Research Unit for Tropical Diseases, International Institute of Cellular and Molecular Pathology, Brussels) and Mr. A. Bernards for their help and advice; Mr. I. C. Eperon (MRC Laboratory of Molecular Biology, Cambridge) for communicating unpublished sequence data; Professor $\mathrm{Ch}$. Weissmann (Institut für Molekularbiologie I, Universität Zürich, Zürich) and Dr. J. Davison (Research Unit of Molecular Biology, International Institute of Cellular and Molecular Pathology, Brussels) for providing us with cloned recombinant DNAs; Dr. G. J. B. Van Ommen (Pediatrics Clinic, Academic Hospital, University of Amsterdam) for advice on isolating and fractionating RNAs; Drs. A. M. Simpson and L. Simpson (Biology Department of Molecular Biology Institute, University of California, Los Angeles, Calif.) for communicating data prior to publication; and Mrs. J. Van den Burg and Mrs. F. Fase-Fowler for expert technical assistance. This work was supported in part by a grant to P.B. from the Foundation for Fundamental Biological Research (BION) which is subsidized by The Netherlands Organization for the Advancement of Pure Research (ZWO).

\section{REFERENCES}

Alwine, J. C., Kemp, D. J., ANd StARK, G. R. (1977). Method for detection of specific RNAs in agarose gels by transfer to diazobenzyloxymethyl-paper and hybridization with DNA probes. Proc. Nat. Acad. Sci. USA 74, 5350-5354.

Berk, A. J., AND SharP, P. A. (1977). Sizing and mapping of early adenovirus mRNAs by gel electro- 
phoresis of $S_{1}$ endonuclease-digested hybrids. Cell 12, $721-732$.

Bolivar, F., Rodriguez, R. L., Greene, P. J., BetLACH, M. C., Heyneker, H. L., And Boyer, H. W. (1977). Construction and characterization of new cloning vehicles. II. A multipurpose cloning system. Gene 2, 95-113.

Boné, G. J., ANd SteinerT, M. (1956). Isotopes incorporated in the nucleic acids of Trypanosoma mega. Nature (London) 178, 308-309.

Borst, P., AND GrIVELL, L. A. (1978). The mitochondrial genome of yeast. Cell 15, 705-723.

Borst, P., ANd FAse-Fowler, F. (1979). The maxicircle of Trypanosoma brucei kinetoplast DNA. Biochim. Biophys. Acta 565, 1-12.

Borst, P., AND HoEIJMakers, J. H. J. (1979a). Kinetoplast DNA. Plasmid 2, 20-40.

Borst, P., AND HoeiJmakers, J. H. J. (1979b). Structure and function of kinetoplast DNA of the African trypanosomes. In "Extrachromosomal DNA: ICNUCLA Symposia on Molecular and Cellular Biology" (D. J. Cummings, P. Borst, I. B. Dawid, S. M. Weissman, and C. F. Fox, eds.), Vol. 15, pp. 515531. Academic Press, New York.

Borst, P., Hoeijmakers, J. H. J., Frasch, A. C. C., SNijders, A., JANSSEN, J. W. G., AND FaseFowler, F. (1980a). The kinetoplast DNA of Trypanosoma brucei: Structure, evolution, transcription, mutants. In "The Organization and Expression of the Mitochondrial Genome" (A. M. Kroon and C. Saccone, eds.), pp. 7-20. North-Holland, Amsterdam.

Borst, P., Fase-Fowler, F., Hoeijmakers, J. H. J., AND FrasCH, A. C. C. (1980b). Variations in maxicircle and mini-circle sequences in kinetoplast DNA from different Trypanosoma bruce i strains. Biochim. Biophys. Acta 610, 197-210.

Borst, P., Fase-Fowler, F., Frasch, A. C. C., Hoeijmakers, J. H. J., and Weijers, P. J. (1980c). Characterization of DNA from Trypanosoma brucei and related trypanosomes by restriction endonuclease digestion. Mol. Biochem. Parasitol. 1, 221246.

Brosius, J., Palmer, M. L., Kennedy, P. J., AND Noller, H. F. (1978). Complete nucleotide sequence of a $16 \mathrm{~S}$ ribosomal RNA gene from Escherichia coli. Proc. Nat. Acad. Sci. USA 75, 48014805.

Brosius, J., Dull, T. J., AND Noller, H. F. (1980). Complete nucleotide sequence of a $23 \mathrm{~S}^{\mathbf{1}}$ ribosomal RNA gene from Escherichia coli. Proc. Nat. Acad. Sci. USA 77, 201-204.

Brün, R., AND Schönenberger, M. (1979). Cultivation and in vitro cloning of procyclic culture forms of Trypanosoma brucei in a semi-defined medium. Acta Trop. 36, 289-292.

Brunel, F., Davison, J., Merchez, M., Borst, P., AND Weijers, P. J. (1980). The use of recombinant DNA techniques in the analysis of Trypanosoma brucei kinetoplast DNA. In "DNA-Recombination Interactions and Repair” (S. Zadrazil and J. Sponar, eds.), pp. 45-54. Pergamon Press, Oxford.

Chen, K. K., And Donelson, J. E. (1980). Sequences of two kinetoplast DNA minicircles of Trypanosoma brucei. Proc. Nat. Acad. Sci. USA 77, 2445-2449.

Cheng, D., AND Simpson, L. (1978). Isolation and characterization of kinetoplast DNA and RNA of Phytomonas davidi. Plasmid 1, 297-315.

Cordingley, J. S., And Turner, M. J. (1980). 6.5 S RNA; preliminary characterisation of unusual small RNAs in T. brucei. Mol. Biochem. Parasitol. 1, 91 96.

Daniels, D. L., DeWet, J, R., and Blattner, F. R. (1980). A new map of bacteriophage lambda DNA. J. Virol. 33, 390-400.

DAwID, I. B. (1972). Mitochondrial protein synthesis. In "Mitochondria: Biogenesis and Bioenergetics; Biomembranes: Molecular Arrangements and Transport Mechanisms'' (S. G. Van den Bergh, P. Borst, L. L. M. Van Deenen, J. C. Riemersma, E. C. Slater, and J. M. Tager, eds.), Vol. 28, pp. 35-51. NorthHolland, Amsterdam.

Donelson, J. E., Majiwa, Ph. A. O., and Williams, R. O. (1979). Kinetoplast DNA minicircles of Trypanosoma brucei share regions of sequence homology. Plasmid 2, 572-588.

ENGLUND, P. T. (1981). Kinetoplast DNA. In "Biochemistry and Physiology of Protozoa" (M. Levandowsky and S. H. Hutner, eds.), 2nd ed., Vol. 4, Academic Press, New York.

Fairlamb, A. H., Weislogel, P. O., Hoeijmakers, J. H. J., AND BoRST, P. (1978). Isolation and characterization of kinetoplast DNA from bloodstream form of Trypanosoma brucei. J. Cell Biol. 76, 293309.

Fouts, D. L., Manning, J. E., And Wolstenholme, D. R. (1975). Physicochemical properties of kinetoplast DNA from Crithidia acanthocephali, Crithidia luciliae and Trypanosoma lewisi. J. Cell Biol. 67, 378-399.

Fouts, D. L., Wolstenholme, D. R., And Boyer, H. W. (1978). Heterogeneity in sensitivity to cleavage by the restriction endonucleases EcoRI and HindIII of circular kinetoplast molecules of Crithidia acanthocephali. J. Cell Biol. 79, 329-341.

Fouts, D. L., AND Wolstenholme, D. R. (1979). Evidence for a partial RNA transcript of the small circular component of kinetoplast DNA of Crithidia acanthocephali. Nucl. Acids Res. 6, 3785-3804.

Garvin, R. T., Hill, R. C., ANd Weber, M. M. (1978). The atypical RNA components of cytoplasmic ribosomes from Crithidia fasciculata. Arch. Biochem. Biophys. 191, 774-781.

Goldbach, R. W., Evers, R. F., and Borst, P. (1978a). Electrophoretic strand separation of long DNAs with poly(U,G) in agarose gels. Nucl. Acids Res. 5, 2743-2754.

Goldbach, R. W., Borst, P., Bollen-De Boer, 
J. E., AND VAN BRUGgen, E. F. J. (1978b). The organization of the ribosomal RNA genes in the mitochondrial DNA of Tetrahymena pyriformis strain ST. Biochim. Biophys. Acta 521, 169-186.

GRAY, M. W. (1979). The ribosomal RNA of the trypanosomatid protozoan Crithidia fasciculata: Physical characteristics and methylated sequences. Canad. J. Biochem. 57, 914-926.

Grivel.., L. A., Arnberg, A. C., Boer, P. H., Borst, P., Bos, J. L., Van Bruggen, E. F. J., Groot, G. S. P., Hecht, N. B., Hensgens, L. A. M., Van OMMEN, G. J. B., AND TABAK, H. F. (1979). Transcripts of yeast mitochondrial DNA and their processing. In "Extrachromosomal DNA: ICN-UCLA Symposia on Molecular and Cellular Biology" (D. J. Cummings, P. Borst, I. B. Dawid, S. M. Weissman, and C. F. Fox, eds.), Vol. 15, pp. 305-324. Academic Press, New York.

Hanahan, D., and Meselson, M. (1980). Plasmid screening at high colony density. Gene 10, 63-67.

HoEIJMAKERS, J. H. J., AND BoRST, P. (1978). RNA from the insect trypanosome Crithidia luciliae contains transcripts of the maxi-circle and not of the mini-circle component of kinetoplast DNA. Biochim. Biophys. Acta 521, 407-411.

Hoeijmakers, J. H. J., Borst, P., VAN den Burg, J., Weissmann, C., and Cross, G. A. M. (1980). The isolation of plasmids containing DNA complementary to messenger RNA for variant surface glycoproteins of Trypanosoma brucei. Gene 8, 391-417.

HradeCNa, Z., AND SzYBalski, W. (1967). Fractionation of the complementary strands of coli phage lambda DNA based on the asymmetric distribution of the poly (I, G)-binding sites. Virology 32, 633-643.

Ito, J., Kawamura, F., ANd Yanofsky, S. (1976). Analysis of $\phi 29$ and $\phi 15$ genomes by bacterial restriction endonucleases EcoRI and HpaI. Virology 70, 37-51.

KLeisen, C. M., AND Borst, P. (1975). Are 50\% of all cellular proteins synthesized on mitochondrial ribosomes in Crithidia luciliae? Biochim. Biophys. Acta 390, 78-81.

Kleisen, C. M., Borst, P., AND WeiJers, P. J. (1975). The structure of kinetoplast DNA. I. Properties of the intact multi-circular complex from Crithidia luciliae. Biochim. Biophys. Acta 390, 155-167.

Kleisen, C. M., Weislogel, P. O., Fonck, K., And Borst, P. (1976a). The structure of kinetoplast DNA. II. Characterization of a novel component of high complexity present in the kinetoplast DNA network of Crithidia luciliae. Eur. J. Biochem. 64, 153-160.

Kleisen, C. M., Borst, P., and Weijers, P. J. (1976b). The structure of kinetoplast DNA. I. The mini-circles of Crithidia luciliae are heterogeneous in base sequence. Eur. J. Biochem. 64, 141-151.

Klukas, C. K., AND Dawid, I. B. (1976). Characterization and mapping of mitochondrial ribosomal RNA and mitochondrial DNA in Drosophila melanogaster. Cell 9, 615-625.

Leder, P., Tiemeier, D., ANd Enquist, L. (1977).
EK-2 derivatives of bacteriophage lambda useful in the cloning of DNA from higher organisms: The lambda $\cdot \mathrm{gt} \cdot W E S$ system. Science 196, 175-177.

Masuda, H., Simpson, L., Rosenblatt, H., and Simpson, A. M. (1979). Restriction map, partial cloning and localization of $9 \mathrm{~S}$ and $12 \mathrm{~S}$ kinetoplast RNA genes on the maxicircle component of the kinetoplast DNA of Leishmania tarentolae. Gene 6, 51-73.

McMaster, G. K., and Carmichael, G. G. (1977). Analysis of single- and double-stranded nucleic acids on polyacrylamide and agarose gels by using glyoxal and acridine orange. Proc. Nat. Acad. Sci. USA 74, 4835-4838.

Morales, N. M., AND RoberTs, J. F. (1978). The ribonucleic acids of Crithidia fasciculata. J. Protozool. $25,140-144$.

Opperdoes, F. R., Borst, P., AND De RiJke, D. (1976). Oligomycin sensitivity of the mitochondrial ATPase as a marker for fly transmissability and the presence of functional kinetoplast DNA in African trypanosomes. Comp. Biochem. Physiol. 55B, 2530.

Osinga, K. A., Evers, R. F., VAn der LaAn, J. C., AND TABAK, H. F. (1981). A putative precursor for the small ribosomal RNA from mitochondria of Saccharomyces cerevisiae. Nucl. Acids Res. y, $1351-1364$.

Penman, S. (1966). RNA metabolism in the HeLa cell nucleus. J. Mol. Biol. 17, 117-130.

Philippsen, P., Thomas, M., Kramer, R. A., and DAvis, R. W. (1978). Unique arrangement of coding sequences for $5 S, 5.85,18 S$ and $25 S$ ribosomal RNA in Saccharomyces cerevisiae as determined by R-loop and hybridization analysis. J. Mol. Biol. 123, 387-404.

Rigby, P. W. J., Dieckmann, M., Rhodes, C., And Berg, P. (1977). Labeling deoxyribonucleic acid to high specific activity in vitro by nick-translation with DNA polymerase I. J. Mol. Biol. 113, 237-251.

Sanders, J. P. M., Heyting, C., And Borst, P. (1975). The organization of genes in yeast mitochondrial DNA. I. The genes for large and small ribosomal RNA are far apart. Biochem. Biophys. Res. Commun. 65, 699-707.

Sanders, J. P. M., Heyting, C., Verbeet, M. Ph., Meijlink, F. C. P. W., ANd Borst, P. (1977). The organization of genes in yeast mitochondrial DNA. III. Comparison of the physical maps of the mitochondrial DNAs from three wild-type Saccharomyces strains. Mol. Gen. Genet. 157, 239-261.

Sanger, F., Air, G. M., Barrell, B. G., Brown, N. L., Coulson, A. R., Fiddes, J. C., Hutchison III, C. A., Slocombe, P. M., ANd SMITH, M. (1977). Nucleotide sequence of $\phi \times 174$ DNA. Nature (London) 265, 687-695.

Sebald, W., Sebald-Althaus, M., and Wachter, E. (1977). Altered amino acid sequence of the DCCDbinding protein of the nuclear oligomycin-resistant mutant AP-2 from Neurospora crassa. In "Mito- 
chondria 1977: Genetics and Biogenesis of Mitochondria"' (Bandlow, W., Schweyen, R. J., Wolf, K., and Kaudewitz, F., eds.), pp. 433-440. De Gruyter, Berlin.

Simpson, L. (1972). The kinetoplast of the hemoflagellates. Int. Rev. Cytol. 32, 139-207.

SimPSON, L., AND LASKY, L. (1975). Kinetoplast messenger RNAs. J. Cell Biol. 67, 402A.

Simpson, L., Simpson, A. M., AND LAsky, L. (1976). Kinetoplast RNA from Leishmania tarentolae culture forms. In "Biochemistry of Parasites and HostParasite Relationships"' (H. Van den Bossche, ed.), pp. 225-228. North-Holland, Amsterdam.

Simpson, L., AND SimPSON, A. M. (1978). Kinetoplast RNA of Leishmania tarentolae. Cell 14, 169178.

Southern, E. M. (1975). Detection of specific sequences among DNA fragments separated by gel electrophoresis. J. Mol. Biol. 98, 503-517.

Spencer, R., AND Cross, G. A. M. (1976). Lability of RNA from the large cytoplasmic ribosomal subunit of the protozoon Crithidia oncopelti. J. Gen. Microbiol. 93, 82-88.

Steinert, M., Van Assel, S., Borst, P., And NewTON, B. A. (1976). Evolution of kinetoplast DNA. In "The Genetic Function of Mitochondrial DNA" (C. Saccone and A. M. Kroon, eds.), pp. 71-81. North-Holland, Amsterdam.

Steinert, M., ANd Van Assel, S. (1980). Sequence heterogeneity in kinetoplast DNA: Reassociation kinetics. Plasmid 3, 7-17.

Thomas, M., AND DaVIS, R. W. (1975). Studies on the cleavage of bacteriophage lambda DNA with EcoRI restriction endonuclease. J. Mol. Biol. 91, 315-328.
Van Ommen, G. J. B., Groot, G. S. P., And Grivell, L. A. (1979). Transcription maps of mtDNAs of two strains of Saccharomyces: Transcription of strainspecific insertions; complex RNA maturation and splicing. Cell 18, 511-523.

Van Ommen, G. J. B., Boer, P. H., Groot, G. S. P., De HaAn, M., Roosendaal, E., Grivell, L. A., HaId, A., ANd SCHWEYEN, R. J. (1980). Mutations affecting RNA splicing and the interaction of gene expression of the yeast mitochondrial loci $C O B$ and OXI3. Cell 20, 173-183.

Wahl, G. M., Stern, M., and Stark, G. R. (1979). Efficient transfer of large DNA fragments from agarose gels to diazobenzyloxymethyl-paper and rapid hybridization using dextran sulfate. Proc. Nat. Acad. Sci. ISSA 76, 3683-3687.

Werner, S., AND Bertrand, H. (1979). Conversion of a mitochondrial precursor polypeptide into subunit 1 of cytochrome oxidase in the mi-3 mutant of Neurospora crassa. Eur. J. Biochem. 99, 463-470.

Wilkie, N. M., Clements, J. B., Boll, W., Mantei, N., Lonsdale, D., AND Weissmann, C. (1979). Hybrid plasmids containing an active thymidine kinase gene of Herpes simplex virus 1. Nucl. Acids Res. 7, 859-877.

Wolstenholme, D. R., Goddard, J. M., and FauRON, C. M.-R. (1979). Structure and replication of mitochondrial DNA from the genus Drosophila. In "Extrachromosomal DNA: ICN-UCLA Symposia on Molecular and Cellular Biology (D. J. Cummings, P. Borst, I. B. Dawid, S. M. Weissman, and C. F. Fox, eds.), Vol. 15, pp. 409-425. Academic Press, New York. 